\title{
História e Filosofia da Ciência na formação docente: trabalhando com animações digitais ${ }^{+{ }^{*}}$
}

Juliana M. Hidalgo ${ }^{2}$

Milton Schivani ${ }^{2}$

Departamento de Física - Universidade Federal do Rio Grande do Norte

Mykaell Martins da Silva ${ }^{2}$

Mestrando em Ensino de Ciências - UFRN

Natal - RN

\section{Resumo}

O presente trabalho discute os resultados da aplicação de uma intervenção didática desenvolvida para o contexto da formação inicial de professores de Física. A intervenção teve como foco essencial promover a reflexão crítica sobre objetos virtuais de aprendizagem com conteúdo histórico, por meio de um processo de desenvolvimento de modificações em tais recursos de modo a adequá-los para uso didático. Nesse sentido, a intervenção se descortinou a partir dos seguintes questionamentos: Qual a qualidade e a pertinência das animações digitais com viés histórico-filosófico voltadas para o ensino de Física? Quais visões de ciência estão implícita ou explicitamente presentes nesses recursos didáticos? O conteúdo apresentado pelos mesmos é adequado do ponto de vista historiográfico? A que objetivos didáticos atendem? É possível propor modificações a esses objetos de modo a adequá-los ao uso didático? Os resultados obtidos na análise da aplicação da intervenção demonstram positivamente a motivação e a participação bem fundamentada e qualificada dos licenciandos em atividade de análise crítica e reelaboração de roteiro para animação digital.

\footnotetext{
+ History and Philosophy of Science in teaching training: working with digital animations

* Recebido: junho de 2018.

Aceito: setembro de 2018.

${ }^{1}$ Os autores agradecem aos pareceristas pelos comentários e sugestões.

2 E-mail: julianahidalgo@fisica.ufrn.br; schivani@fisica.ufrn.br; mykaell.silva@uece.br
} 
Palavras-chave: Formação Docente; História e Filosofia da Ciência; Objetos Virtuais; Animações Digitais.

\begin{abstract}
This work presents the outcomes of the use of a didactic sequence developed for the context of pre-service physics teachers training. The intervention had as its essential focus advancing a critical reflection on virtual learning objects with historical content, through a process of development of changes in such resources in order to adapt them for didactic use. In this sense, with the intention of contributing to the reflection on virtual learning objects, we have proposed a didactic sequence following some essential questions: What is the quality and relevance of the digital animations with historical-philosophical content towards the teaching of physics? What views of science are implicitly or explicitly present in these didactic resources? Is the content presented by them historically appropriate? What educational objectives do they serve? Is it possible to propose changes to these objects in order to adapt them to the didactic use? The outcomes provided show the great interest and the well-founded and qualified engagement of the pre-service teachers in activities of critical analysis and re-elaboration of script for digital animation.
\end{abstract}

Keywords:

Keywords: Teacher Training; History and Philosophy of Science; Virtual Objects; Digital Animations.

\title{
I. Introdução
}

É amplamente reconhecido pela área de ensino de ciências, em nível nacional e internacional, o importante papel que a História e Filosofia da Ciência (HFC) desempenham na educação científica (MATTHEWS, 1995; CARVALHO; GIL PÉREZ, 1998; GIL PÉREZ et al., 2001; PEDUZZI, 2001; SILVA, 2006; PEDUZZI; MARTINS; FERREIRA, 2012 BOAS et al., 2013). Argumenta-se que a abordagem histórico-filosófica possibilita contextualizar o conhecimento científico como tentativa de resolução de problemas em contraposição a uma visão aproblemática e a-histórica da ciência (GIL PÉREZ et al., 2001). Defende-se, por exemplo, que:

[...] A história, a filosofia [...] da ciência [...] podem humanizar as ciências e aproximá-las dos interesses pessoais, éticos, culturais e políticos da comunidade; podem 
tornar as aulas de ciências mais desafiadoras e reflexivas, permitindo, deste modo, o desenvolvimento do pensamento crítico; podem contribuir para um entendimento mais integral da matéria científica, isto é, podem contribuir para a superação do "mar de falta de significação" que se diz ter inundado as salas de aula de ciências, onde fórmulas e equações são recitadas sem que muitos cheguem a saber o que significam [...] (MATTHEWS, 1995, p. 165).

Apesar de todas essas potencialidades, a inserção efetiva da HFC na educação científica enquanto abordagem didática ainda é tímida e se configura como um desafio (MARTINS, 2006; MARTINS, 2007; TEIXEIRA; GRECA; FREIRE, 2009; PEDUZZI; MARTINS; FERREIRA, 2012; FONSECA et al., 2017). Segundo Martins, três "principais barreiras" precisariam ser transpostas:

[...] (1) a carência de um número suficiente de professores com a formação adequada para pesquisar e ensinar de forma correta a história das ciências; (2) a falta de material didático adequado (textos sobre história da ciência) que possa ser utilizado no ensino; e (3) equívocos sobre a natureza da história da ciência e seu uso na educação [...] (MARTINS, 2006, p. xxviii, grifo nosso).

A literatura acadêmica vem frisando a necessidade de se atuar justamente nessa lacuna, ou seja, explorar na formação docente "a natureza da história da ciência". Parte-se do princípio de que o professor não deve recorrer acriticamente a qualquer História da Ciência, mas sim, é necessário que o profissional reflita sobre "a qual história da ciência se deve recorrer para se atingir os objetivos educacionais" (BALDINATO; PORTO, 2008, p.1). Trata-se de englobar na formação docente elementos que possibilitem compreender o que a História da Ciência ${ }^{3}$ é, como ela é escrita e quais os seus fundamentos historiográficos (DUARTE, 2004; GOULART, 2005; BALDINATO; PORTO, 2008; PEREIRA, 2009; FERREIRA; FERREIRA, 2010). Sem que haja a intenção de transformá-los em historiadores da ciência, enfatizase, por exemplo, que

[...] é preciso explicitar que diferentes concepções de ciência subjazem a concepções historiográficas distintas. Um modelo historiográfico continuísta, internalista, acumulativo, que olha para o passado buscando os "precursores" das ideias científicas atuais, avaliando o pensamento de outras épocas por meio dos critérios da ciência de hoje, não contribuirá para a construção de uma visão de ciência condizente com os objetivos atuais do ensino. [...]. Para que o educador em ciência tenha condições de lidar com essa problemática, é necessário que, em algum momento,

\footnotetext{
3 Ainda que o termo "História da Ciência" figure aqui no singular, reconhece-se que não há uma abordagem única para a historiografia da ciência: "A historiografia da ciência analisa os episódios históricos da ciência, e tem como ponto de partida documentos e fatos relacionados à ciência. Porém, vale ressaltar que esta análise histórica está carregada de crenças e filosofias do historiador, pois a leitura que ele faz dos documentos pode ser direcionada pela sua própria formação. Logo, surgem as várias abordagens historiográficas presentes na HC [...]”. (OLIVEIRA, SILVA, 2011, p. 3; grifo nosso).
} 
ele seja apresentado às questões historiográficas da ciência. [...] (BALDINATO; PORTO, 2008, p. 8; grifo nosso).

Reconhecer a impossibilidade de se desvincular crenças e valores pessoais das concepções implícitas em qualquer narrativa sobre as ciências, permite ao professor selecionar as versões históricas coerentes com os objetivos de sua prática pedagógica, ou discutir criticamente narrativas consideradas inadequadas (FORATO; PIETROCOLA; MARTINS, 2011, p. 53; grifo nosso).

Admite-se assim que o conhecimento de pressupostos básicos da historiografia fundamenta "uma leitura mais crítica das versões históricas presentes no ensino de ciências" (FORATO; PIETROCOLA; MARTINS, 2011, p. 36). Permite ao docente perceber que

\begin{abstract}
[...] a história da ciência, da maneira como é apresentada nos livros didáticos, não contribui para que sejam atingidos os objetivos educacionais preconizados por diversos documentos [...] A história da ciência não está sendo apresentada da maneira sugerida pela nova historiografia da ciência (VIDAL, 2009, p. 6).
\end{abstract}

Se o que se pretende no ensino médio é desenvolver entre os alunos a ideia de que a ciência é um empreendimento humano, coletivo, caracterizada por processos que preveem a contínua crítica ao próprio conhecimento cientifico estabelecido, e que interage com o meio social em que é produzida, então os livros didáticos precisam incorporar formas de se abordar a história da ciência que favoreçam a construção dessas concepções (VIDAL, 2009, p. 6).

A nova historiografia ${ }^{4}$ da ciência se alinha a concepções de visões de ciência mais complexas. Ao preconizar o equilíbrio entre internalismo e externalismo, subsidia a explicitação da dinâmica de relações entre o desenvolvimento conceitual da ciência e as múltiplas influências que a circundam. A inserção didática de uma História da Ciência pautada pela nova historiografia ${ }^{5}$ pode colaborar para que se atinja uma das principais competências em Física esperadas ao final da educação básica: a compreensão da construção do conhecimento físico

\footnotetext{
${ }^{4}$ Contribuições de autores como Alexandre Koyré, Gaston Bachelard e Thomas Kuhn foram fundamentais para o questionamento do conceito de desenvolvimento por acumulação e a gênese da "nova historiografia", em contraposição à "velha historiografia da ciência", linear e cumulativa. A expressão "nova historiografia" é recorrente nos trabalhos que podem ser consultados para aprofundamento sobre essa temática: OLIVEIRA, B. J.; CONDÉ, M. L. L. Thomas Kuhn e a nova historiografia da ciência. Ensaio - Pesquisa em Educação em Ciências, Belo Horizonte, v. 4, n. 2, p. 143-153, 2002; OLIVEIRA, J. C. P. Sobre a gênese (e justificação) da "nova historiografia”. Pp. 272-277. In: MARTINS, R. A.; SILVA, C. C.; FERREIRA, J. M. H.; MARTINS, L. A. P. (org.). Filosofia e História da Ciência no Cone Sul. Seleção de trabalhos do $5^{\circ}$ Encontro. Campinas: AFHIC, 2008; ALFONSO-GOLDFARB, A. M. O que é História da Ciência? São Paulo: Brasiliense, 1994; ALFONSOGOLDFARB, A.M.; BELTRAN, M. H. R. (orgs). Escrevendo a História da Ciência: tendências, propostas e discussões historiográficas. São Paulo: EDUC/Livraria Editora da Física/FAPESP, 2004.
}

5 Uma discussão, especificamente direcionada à formação de professores, sobre a temática historiografia da ciência pode ser acessada em dissertação de mestrado profissional realizada por Nicácio (2015), que desenvolveu produto educacional para esse público. A referida dissertação foi orientada por um dos autores do presente artigo. 
como um processo histórico, em estreita relação com as condições sociais, políticas e econômicas de determinada época (BRASIL, 2002).

Para que essa inserção seja alcançada é preciso, ainda, dar atenção a aspectos essenciais na formação docente que vão além da fundamentação historiográfica:

É preciso refletir sobre o como fazer. Embora muitos sujeitos afirmem a importância da HFC como uma estratégia didática facilitadora na compreensão de conceitos, boa parte dos questionados, contraditoriamente, não percebe de forma clara o uso da HFC como tal (MARTINS, 2007, p. 127; grifo nosso).

Além do próprio conteúdo [da História da Ciência], é preciso refletir sobre os aspectos metodológicos e oferecer alternativas, vivências, experiências (PEREIRA; MARTINS, 2011, p. 250; grifo nosso).

Dentre as estratégias didático-metodológicas para a inserção de aspectos da HFC no contexto educacional estão o desenvolvimento de roteiros e a encenação de peças teatrais (FORATO, 2009; HENRIQUE; COLOMBO JÚNIOR, 2011), a leitura e interpretação de fontes primárias (VANNUCCHI, 1997; BATISTA et al., 2015; SILVA; GUERRA, 2015; FONSECA et al, 2017), a discussão de narrativas histórico-pedagógicas (FORATO, 2009; DRUMMOND et al., 2015), a reconstrução de experimentos históricos (MEDEIROS; MONTEIRO JUNIOR, 2001; RINALDI; GUERRA, 2011; BOSS, 2011) e o uso de objetos virtuais oriundos das tecnologias da informação e comunicação (RODRIGUES; ZIMMERMANN; HARTMANN, 2012; PEDUZZI; TENFEN; CORDEIRO, 2012; COSTA, 2015; SOUZA; SILVEIRA; SILVA, 2016). É preciso que o docente em formação seja apresentado a essa diversidade de caminhos.

No caso específico do uso de objetos virtuais, destacamos o potencial didático das animações digitais com conteúdo histórico. Com características notadamente lúdicas, esses recursos podem despertar o interesse e a atenção do aluno:

\footnotetext{
Uma das novidades do mundo contemporâneo e que mexe com as demandas das pessoas, principalmente os adolescentes, são as Tecnologias da Comunicação e da Informação, principalmente aquelas associadas ao universo da Internet. As animações virtuais fazem parte desse universo (VINHA, 2007, p. 90).
}

As animações ainda são pouco disseminadas do contexto escolar. Podem, no entanto, se constituir como recursos que contribuem para a aprendizagem de alunos. Podem ir além de um papel meramente motivacional:

Animações virtuais com fins didáticos também são denominadas de objetos de aprendizagem e geralmente se constituem em uma mídia para se veicular ideias, mensagens e conteúdos considerados importantes em termos de formação escolar (VINHA, 2007, p. 88). 
Utilizar-se das animações ao longo do processo de instrução leva a um meio termo, no qual elas podem ser fonte de debates de conceitos novos para o aprendiz, assim como podem elucidar conceitos já assimilados, e colocá-los sob diferentes perspectivas. Desse modo, caso esses conceitos consistam em subsunçores iniciais para determinado indivíduo ou grupo, eles podem passar a ser enriquecidos e ampliados. (PEDUZZI; TENFEN; CORDEIRO, 2012, p. 780).

Conquanto que a utilização didática de animações de conteúdo histórico possa ser benéfica, é preciso estar atento à qualidade desses objetos virtuais, muitas vezes disponíveis em sítios da internet e acessíveis ao professor. O desenvolvimento desses recursos pode envolver equipe técnica não especializada em HFC ou com conhecimentos epistemológicos e didático-pedagógicos insuficientes para trabalhar com abordagens histórico-filosóficas. Nesse caso, as animações podem ter como foco exclusivamente mostrar os "grandes produtos" da ciência e os "super-heróis", cientistas geniais, que conseguiram descobrir por meio de insights a "verdadeira" face da natureza. Esses relatos pseudo-históricos se parecem mais com contos de fada do que com a complexa relação da ciência produzida por seres humanos em seu contexto sociocultural (ALLCHIN, 2003). Não raro, objetos virtuais que procuram expressar alguma informação histórica sobre a ciência e a construção do conhecimento científico o fazem de forma tão vaga que partilham ideias simplistas sobre a História da Ciência e a Natureza da Ciência. Estas descrições descontextualizadas ou mal contextualizadas do ponto de vista histórico se comunicam com visões rudimentares sobre a ciência.

Os recursos visuais empregados nessas animações também podem levar a erros de interpretação. Anacronismos podem estar associados, por exemplo, ao uso de imagens de aparatos experimentais compostos por materiais que não existiam nos períodos históricos referidos nas animações. Erros históricos podem ser caracterizados em animações que trazem experimentos não utilizados nos episódios históricos aos quais se referem. Como equívocos gerais, não inerentes apenas às animações digitais de conteúdo histórico, podem ocorrer, ainda, distorções de ordem gráfica. A aparência física e visual distorcida ou estereotipada de personagens e a ambientação com cenários e objetos desproporcionais podem acarretar comprometimento negativo em eventual uso dessas animações no contexto educacional.

A título de exemplificação desse tipo de problema, apresentamos na Fig. 1 aspecto de uma animação interativa disponível no portal do Ministério da Educação do Brasil em colaboração com o Banco Internacional de Objetos Educacionais ${ }^{6}$. O referido objeto apresenta conteúdo histórico sobre o experimento de Torricelli, e é indicado para consulta a estudantes do $6^{\circ}$ ano do ensino fundamental em seção intitulada "Mundo Virtual" de um livro didático recente para o Ensino de Ciências (GEWANDSZNADJER, 2015). Em um dos quadros sequenciais que compõem esse objeto virtual, a animação interativa permite variar a altitude de

\footnotetext{
${ }^{6}$ Disponível em: <http://objetoseducacionais2.mec.gov.br/handle/mec/14752>. Acesso em: 01 jun. 2018.
} 
um balão, sendo observada na lateral da tela a variação da altura da coluna de mercúrio no experimento de Torricelli de acordo com a altitude atingida pelo balão.

Nota-se um erro de proporcionalidade se considerarmos a altitude apresentada em escala na lateral direita da figura. $O$ balão teria altura da ordem de $1000 \mathrm{~m}$. No entanto, o maior balão do mundo hoje tem cerca de 100 metros. A animação pode induzir a crença de que existiam balões desse tipo na época de Evangelista Torricelli (1608-1647), o que não é verdade. Além de distorções sob o ponto de vista gráfico e anacronismos, o referido objeto virtual se fundamenta sob uma perspectiva empirista-indutivista da ciência: o experimento crucial comprobatório sobre a pressão atmosférica na subida de uma montanha pôs fim às incertezas.

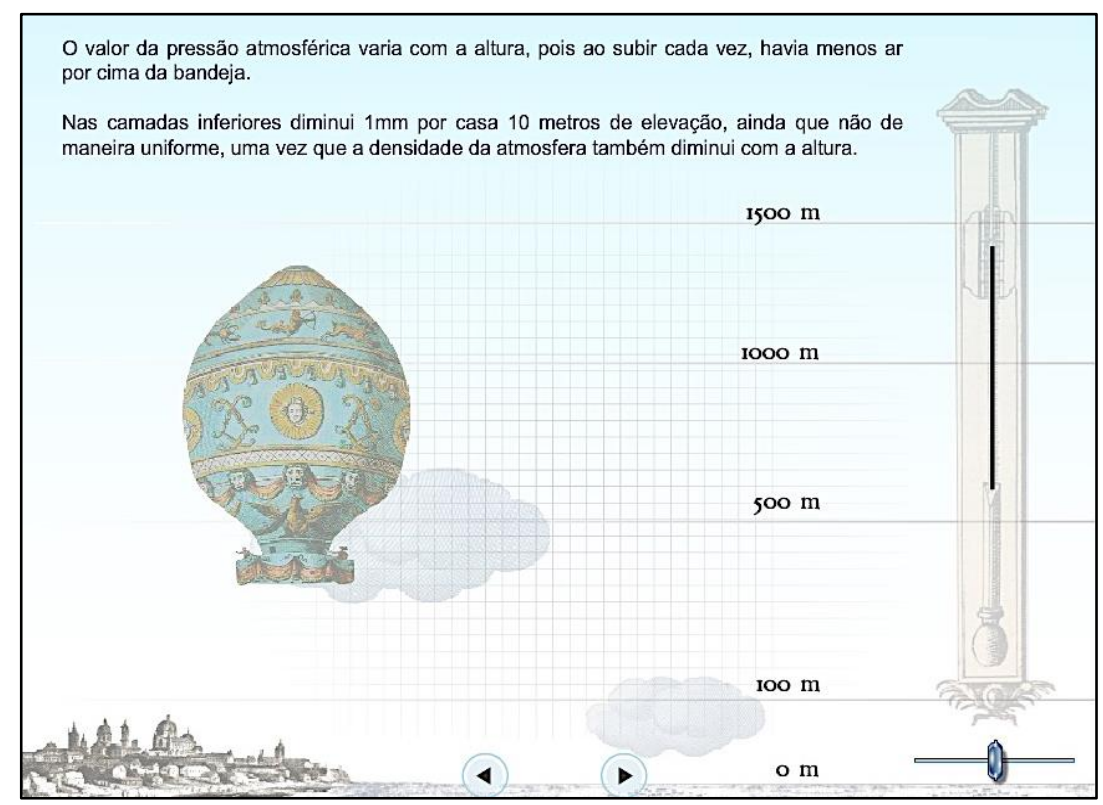

Fig. 1 -Um dos quadros da animação interativa sobre o experimento de Torricelli. Fonte: Imagem obtida pelo autor por captura de tela.

Sua eventual utilização didática demandaria, portanto, um olhar crítico e reflexivo por parte do professor. Como bem destaca Mercado: "um dos pontos fundamentais em qualquer iniciativa que contemple a introdução de novas tecnologias na educação é a sensibilização e iniciação dos professores nas novas tecnologias" (MERCADO, 1999, p. 21). Porém, para que essa utilização seja bem fundamentada do ponto de vista epistemológico, a História e a Filosofia da Ciência precisam estar presentes na formação docente, uma vez que "podem melhorar a formação do professor auxiliando o desenvolvimento de uma epistemologia da ciência mais rica e mais autêntica" (MATTHEWS, 1995, p. 165).

Nesse sentido, buscamos atuar na formação docente contribuindo com elementos que visam à inserção didática de objetos virtuais de conteúdo histórico. Quais as qualidade e pertinência das animações com viés histórico-filosófico voltadas para o ensino de Física? Quais visões de ciência estão implícita ou explicitamente presentes nesses recursos didáticos? $\mathrm{O}$ 
conteúdo apresentado pelos mesmos é adequado do ponto de vista historiográfico? A que objetivos didáticos esses materiais atendem? É possível propor modificações a esses objetos de modo a adequá-los ao uso didático?

Desenvolvemos para o contexto da formação inicial de professores de Física uma intervenção didática centrada fundamentalmente em promover a reflexão crítica sobre objetos virtuais de aprendizagem com conteúdo histórico, por meio de um processo de desenvolvimento de modificações em tais recursos de modo a adequá-los para uso didático. O presente trabalho apresenta a aplicação dessa intervenção durante o segundo semestre de 2017 em uma turma da disciplina de História e Filosofia da Ciência na Licenciatura em Física da Universidade Federal do Rio Grande do Norte. Traz-se um relato, porém com certo caráter analítico, sendo o referencial teórico as concepções sobre História da Ciência e Filosofia da Ciência tratadas nas aulas e referenciadas ao longo desse trabalho.

\section{Caracterização geral da intervenção didática}

A disciplina de História e Filosofia da Ciência é um componente obrigatório na atual estrutura curricular da Licenciatura em Física da Universidade Federal do Rio Grande do Norte, sendo alocada no último período regular do curso. No segundo semestre de 2017, em média, 19 licenciandos frequentaram as aulas e participaram das atividades propostas, sendo organizados em grupos em algumas delas.

Para a intervenção didática, a título de temática histórica foi escolhido como recorte o desenvolvimento do conceito de pressão atmosférica e as discussões sobre o vazio, em especial os trabalhos de Evangelista Torricelli e Blaise Pascal. Por meio de uma pesquisa prévia em repositórios ${ }^{7}$ com acesso gratuito na internet foram selecionados três objetos virtuais relacionados à temática pressão atmosférica: uma simulação produzida pela Wolfram intitulada "Torricelli's Experiment" "; uma animação interativa com sequência de quadros sobre o experimento de Torricelli ${ }^{9}$, disponibilizada pelo Banco Internacional de Objetos Educacionais (a mesma citada anteriormente na introdução); uma animação desenvolvida pela TED-Ed intitulada "The history of the barometer (and how it works)", ".

Dentre os objetos discutidos coletivamente, a animação produzida pela TED-Ed se destacou: o caráter fortemente atrativo e lúdico se conjugava a inadequações visíveis aos li-

\footnotetext{
7 São eles: Banco Internacional de Objetos Educacionais (http://objetoseducacionais2.mec.gov.br). Portal do Professor (http://portaldoprofessor.mec.gov.br). RIVED (http://rived.mec.gov.br/). PROATIVA (http://www.proativa.virtual.ufc.br). PHET (https://phet.colorado.edu). Wolfram Demonstrations Project (http://demonstrations.wolfram.com). LAPREN (http://www.pucrs.br/logos/lapren/). MERLOT (http://www.calstate.edu/itl/resources/merlot/). MITOpencourseware (https://ocw.mit.edu/index.htm). TED-Ed (https://ed.ted.com).

8 Disponível em: <http://demonstrations.wolfram.com/TorricellisExperiment/>. Acesso em: 01 jun. 2018.

${ }^{9}$ Disponível em: <http://objetoseducacionais2.mec.gov.br/handle/mec/14752>. Acesso em: 01 jun. 2018.

10 Disponível em: <https://ed.ted.com/lessons/the-history-of-the-barometer-and-how-it-works-asaf-bar-yosef〉. Acesso em: 01 jun. 2018.
} 
cenciandos, se considerados os fundamentos previamente estudados pela turma em etapa formativa da intervenção didática ${ }^{11}$. Em decorrência da motivação manifestada pelos licenciandos, julgou-se conveniente dar continuidade a um trabalho formativo mais aprofundado a partir da referida animação. O prosseguimento da intervenção, portanto, foi direcionado para esse objeto virtual específico. Por motivo de limitações de espaço não traremos aqui detalhes sobre a discussão coletiva dos demais objetos virtuais ${ }^{12}$.

O presente artigo apresenta a aplicação da intervenção, dividida em quatro momentos:

- Fundamentação para a inserção didática da HFC;

- Análise individual dos objetos virtuais pelos licenciandos: a animação "The history of the barometer" em destaque;

- Discussão coletiva da compilação de comentários individuais (síntese da turma);

- Atividade de reelaboração do roteiro da animação digital pelos grupos.

\section{Detalhamento da intervenção didática}

\section{III.1 Momento 1 - Fundamentação para a inserção didática da HFC}

A primeira etapa da intervenção direcionada à formação docente contemplou fundamentos teóricos para a inserção didática da HFC. Foram realizadas 11 aulas expositivas dialogadas com cerca de 100 minutos de duração cada, ao longo das quais se incentivou a participação dos estudantes em todos os momentos de discussão (Quadro 1). Ao final de cada aula, os estudantes realizaram atividade escrita individual, o que permitiu o acompanhamento constante da evolução dos participantes em relação à temática abordada ${ }^{13}$.

\footnotetext{
${ }^{11}$ Essa etapa será explicada em detalhe em seção subsequente.

12 Esses objetos virtuais utilizados para discussão com os licenciandos são de naturezas distintas. A proposta de "adequação" realizada com os licenciandos restringiu-se à animação "The history of the barometer". Encontram-se em desenvolvimento, também em intervenções na formação docente, iniciativas análogas (de adequação) a respeito dos dois outros objetos virtuais citados. Deixaremos indicações mais detalhadas sobre esses objetos para um momento oportuno.
}

13 Essa etapa foi baseada principalmente nos seguintes trabalhos: ALFONSO-GOLDFARB. A. M. O que é História da Ciência? São Paulo: Brasiliense, 1994; CHALMERS, A. F. O que é a ciência, afinal? São Paulo: Brasiliense, 1993; BATISTA, R. P.; MOHR, A.; FERRARI, N. A análise da história da ciência em livros didáticos do ensino fundamental em Santa Catarina. In: ENCONTRO NACIONAL DE PESQUISA EM EDUCAÇÃO EM CIÊNCIAS, 2007. Atas... 2007; FERREIRA, J. M. H.; MARTINS, A. F. P. Apostila da disciplina de História e Filosofia da Ciência do Ensino à Distância/UFRN. Natal: SEDIS/UFRN, 2009; FONSECA, D. S. et al. Pressão atmosférica e natureza da ciência: uma sequência didática englobando fontes primárias. Caderno Brasileiro de Ensino de Física, Florianópolis, v. 34, n. 1, p. 64-108, maio 2017; FORATO, T. C. M.; PIETROCOLA, M.; MARTINS, R. A. Enfrentando obstáculos na transposição didática da história da ciência para a sala de aula. p. 123-154. In: PEDUZZI, L. O. Q.; MARTINS, A. F. P., FERREIRA, J. M. H. (org.). Temas de história e filosofia da ciência no ensino. Natal: EDUFRN, 2012; MARTINS, L. A-C P. História da ciência, objetos, métodos e problemas. Ciência \& Educação, v. 11, n. 2, p. 305-317, 2005; MAGIE, W. F. A source book in physics. Cambridge, MA, Harvard University Press, 1969; MARTINS, R. A. Seria possível uma história da ciência totalmente neutra, sem qualquer aspecto whig? Boletim de História e Filosofia da Biologia, São Paulo, v. 4, n. 3, p. 4-7, set. 2010; MARTINS, R. A. O vácuo e a pressão atmosférica, da Antiguidade a Pascal. Cadernos de História e Filosofia da Ciência, Campinas, v. 1, n. 3, p. 9-48, 1989; MARTINS, R. A. Tratados Físicos de Blai- 
Quadro 1 - Atividades desenvolvidas na etapa formativa inicial.

\begin{tabular}{|c|l|}
\hline \multicolumn{2}{|c|}{ Fundamentação para a inserção didática da HFC - Atividades desenvolvidas } \\
\hline Aula & \multicolumn{1}{c|}{ Tópico } \\
\hline $\mathbf{1}$ & Problematização da visão comum de História da Ciência \\
\hline $\mathbf{2 - 3}$ & Aulas expositivas dialogadas: Fundamentos historiográficos, visões de ciência e implicações didáticas \\
\hline $\mathbf{4}$ & Análise e discussão: recortes de livros didáticos para o Ensino Médio \\
\hline $\mathbf{5 - 6}$ & Aulas expositivas dialogadas: argumentos sobre a HFC no Ensino \\
\hline $\mathbf{7}$ & Análise e discussão: História da Ciência em recortes de editais do PNLD e da legislação educacional \\
\hline $\mathbf{8}$ & $\begin{array}{l}\text { Análise e discussão: recortes de livros didáticos que fazem referência ao conceito de pressão atmosfé- } \\
\text { rica }\end{array}$ \\
\hline $\mathbf{9}$ & $\begin{array}{l}\text { Leitura e discussão coletiva sobre três fontes primárias relacionadas aos trabalhos de Torricelli e } \\
\text { Pascal }\end{array}$ \\
\hline $\mathbf{1 0 - 1 1}$ & Leitura de narrativa histórica: contextualização das discussões sobre vazio e pressão atmosférica \\
\hline
\end{tabular}

Partiu-se de uma problematização da visão comum de História da Ciência, quer seja, como um conjunto de biografias dos principais cientistas e suas descobertas, ou, ainda, uma sequência cronológica de fatos marcantes. A existência de uma única História da Ciência verdadeira foi problematizada. Em seguida, transcorreu uma exposição dialogada sobre as transformações da historiografia da ciência ao longo do século XX. Foram compreendidos e contextualizados termos como História Pedigree, História Whig, hagiografia, anacronismo, internalismo e externalismo ${ }^{14}$. Os estudantes tiveram noções básicas sobre os recursos utilizados pelos historiadores, como fontes secundárias e primárias. Buscou-se sensibilizá-los quanto à percepção de que atualmente a História da Ciência tem como objeto de estudo tudo aquilo que foi proposto ou aceito como conhecimento em alguma época, contexto e cultura.

Ao longo dessa etapa, foram recorrentes as discussões sobre implicações didáticas desses elementos. Discutiu-se a respeito das características da História da Ciência presente em livros didáticos da educação básica. Relações entre historiografia e visões sobre a ciência foram exploradas. Por exemplo, uma História estritamente internalista pode levar a uma percepção de neutralidade da ciência. Uma História da Ciência restrita a dados biográficos dos grandes cientistas e suas respectivas descobertas pode se relacionar a visões de ciência individualistas e empiristas-indutivistas. Convidados à análise de recortes de materiais didáticos ${ }^{15}$, os

se Pascal. Seleção e tradução. Cadernos de História e Filosofia da Ciência, Campinas, v. 1, n. 3, p. 49-167, 1989; PAGLIARINI, C. R.; SILVA, C. C. A Estrutura dos Mitos Históricos nos Livros de Física. In: ENCONTRO DE PESQUISA EM ENSINO DE FÍSICA, 2006. Atas... 2006; PEDUZZI, L. O. Q. Sobre a História e o Ensino da Física. p. 9-19. In: Evolução dos Conceitos da Física. Florianópolis: Editora da UFSC, 2011; PRESTES, M. E. B. O whiggismo proposto por Herbert Butterfield. Boletim de História e Filosofia da Biologia, São Paulo, v. 4, n. 3, p. 2-4, set. 2010; SOUSA, R. G. Anacronismo. Brasil Escola. Disponível em: <http://brasilescola.uol.com.br/historia/anacronismo.htm>. Acesso em: 03 jun. 2018.

14 A História da Ciência do tipo hagiográfica faz apologia às virtudes heroicas e grandes realizações dos pesquisadores. A história anacrônica, Whig, descreve os fatos do passado com base no que atualmente é aceito. A história Pedigree busca os precursores dos conhecimentos científicos. Essas características historiográficas remontam aos primeiros trabalhos de historiadores da ciência profissionais das décadas iniciais do século XX. Para aprofundamento sobre a temática são recomendados trabalhos citados em nota de rodapé precedente.

15 Os recortes de livros podem ser verificados em artigo publicado por um dos autores do presente trabalho (HIDALGO et al., 2018). 
estudantes perceberam nas referências a episódios históricos traços de História Whig, anacronismos, História Pedigree, bem como visões simplistas sobre a ciência. Perceberam que a História da Ciência geralmente presente no contexto escolar pouco se aproxima de um modelo contextualizado à luz da atual historiografia da ciência.

Em continuidade, foram trazidos à tona os argumentos relacionados à História da Ciência no Ensino. Seguiu-se uma exposição dialogada sobre os debates da década de 1970, com os argumentos de Stephen Brush, Martin Klein e Thomas Kuhn, passando pela aproximação defendida por Michael Matthews na década de 1990 até a argumentação atual relacionada à inserção didática da temática Natureza da Ciência por meio de episódios históricos.

Com base na referida fundamentação, os estudantes foram convidados ao exame de indicações relativas à História da Ciência em recortes de editais do Programa Nacional do Livro Didático e da legislação educacional (Orientações Curriculares para o Ensino Médio; Diretrizes Curriculares Nacionais da Educação Básica; Base Nacional Comum Curricular e Matriz de Referência para o ENEM) ${ }^{16}$. Perceberam que a História da Ciência recomendada remete a características da nova historiografia e a visões mais complexas sobre a ciência.

A etapa formativa teve continuidade já com encaminhamentos específicos relacionados à temática histórica especifica da intervenção. Realizou-se, coletivamente, uma análise de trechos de livros didáticos 17 do Ensino Médio que fazem referência ao conceito de pressão atmosférica, e trazem, geralmente, o experimento de Evangelista Torricelli e alguma referência ao trabalho de Blaise Pascal. A análise foi centrada na percepção de quais eram os elementos históricos citados e que características historiográficas e visões de ciência estavam associadas. Naquele momento, os licenciandos ainda não haviam entrado em contato com o tema histórico específico. Dessa forma, a intenção foi sensibilizá-los quanto à compreensão de que algumas eventuais inadequações nos conteúdos históricos podem ser percebidas pelo professor, ainda que o mesmo pouco saiba sobre um determinado tema histórico. Podem ser notadas, por exemplo, narrativas do tipo empiristas-indutivistas, restritas a dados cronológicos e descobertas pontuais em datas específicas, atribuídas a indivíduos isolados.

Curiosos sobre aqueles episódios históricos, os estudantes participaram de discussão coletiva sobre três fontes primárias: uma carta na qual Evangelista Torricelli descreve a Michelangelo Ricci suas pesquisas ${ }^{18}$; uma carta na qual Blaise Pascal solicita ao cunhado Florin

\footnotetext{
16 Os recortes de editais do PNLD e da legislação educacional analisados podem ser verificados em artigo publicado por um dos autores do presente trabalho (HIDALGO et al., 2018). Esses recortes podem também ser acessados em dissertação de mestrado profissional desenvolvida por Souza (2018). Na ocasião, foram discutidos por professores da Educação Básica em formação continuada, em aplicação de produto educacional direcionado para esse público. A referida dissertação foi orientada por um dos autores do presente artigo.

17 Os recortes podem ser verificados em artigo publicado por um dos autores do presente trabalho (HIDALGO et al. 2018).

${ }^{18}$ Foi utilizada tradução realizada pelos autores a partir de documento original disponibilizado por Magie (1969).
} 
Périer que realize o "experimento ordinário do vácuo" ao longo da subida de uma montanha; a carta na qual Périer responde a Pascal descrevendo o experimento ${ }^{19}$.

A professora responsável pela disciplina (uma das autoras do presente trabalho) mediou a interpretação coletiva dos documentos históricos, provendo informações sobre o contexto histórico das discussões a respeito do vazio e da pressão atmosférica. Os estudantes participaram ativamente da discussão, trazendo contribuições significativas em relação a contrastes percebidos entre o que havia nos livros didáticos analisados previamente e o conteúdo dos referidos documentos históricos. Em seguida, como atividade individual extraclasse, recomendou-se aos licenciandos a leitura da seção "(Breve) Contextualização Histórica", apresentada em artigo acadêmico sobre a inserção didática da referida temática histórica (FONSECA et al., 2017). A leitura trouxe informações a fim de contextualizar historicamente os trabalhos de Torricelli e Pascal.

\section{III.2 Momento 2 - Análise individual dos objetos virtuais pelos licenciandos: a animação "the history of the barometer" em destaque}

A etapa formativa prévia, descrita na seção anterior, trouxe fundamentação essencial para as discussões coletivas sobre três objetos virtuais nas aulas subsequentes ${ }^{20}$. Particularmente, a animação desenvolvida pela TED-Ed intitulada "The history of the barometer (and how it works)" chamou a atenção dos licenciandos (Fig. 2) ${ }^{21}$.

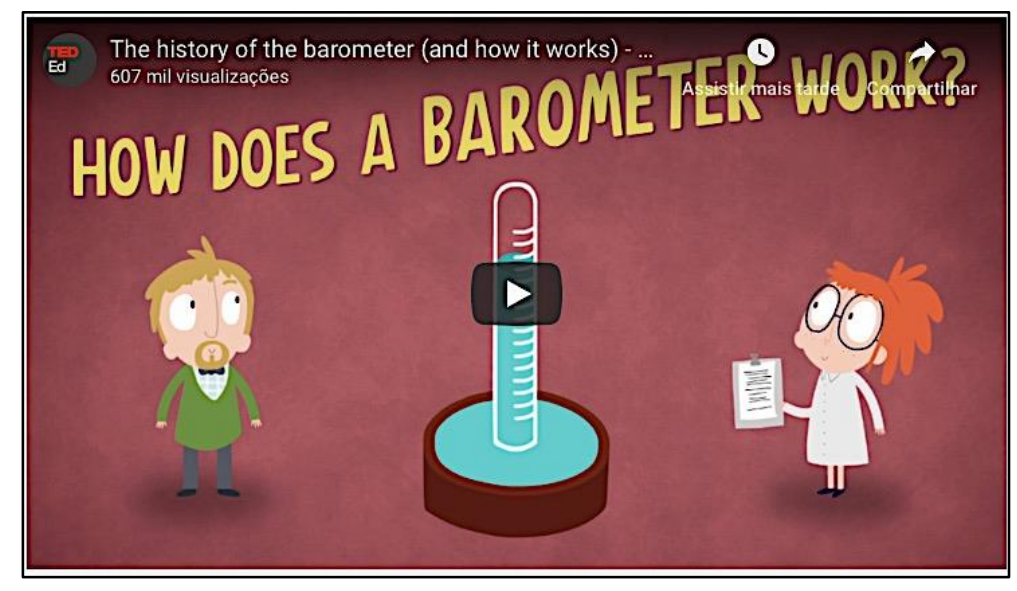

Fig. 2 - Tela inicial em mídia social da animação sobre o Barômetro.

Fonte: Imagem obtida pelos autores por captura de tela.

\footnotetext{
${ }^{19}$ Foi utilizada a correspondência entre Pascal e Périer traduzida pelo historiador da ciência Roberto de Andrade Martins (1989b).

20 Por limitações de espaço nos restringiremos aqui à animação "The history of the barometer", deixando as discussões sobre os demais objetos virtuais para momento oportuno.

${ }^{21}$ Equipe de criação: Asaf Bar-Yosef (Educador), Stephen Whittle (Produtor), Mara Fradella (Animador), Addison Anderson (Narrador).
} 
Nessa animação, os personagens não falam, mas executam ações e demonstram emoções, enquanto um narrador descreve os episódios históricos apresentados nos quadros. São apresentados pesquisadores e eventos relacionados ao desenvolvimento do barômetro. $\mathrm{O}$ funcionamento do instrumento e suas utilidades são apontados. Utilizamos a versão original com o áudio da narração em inglês e traduzimos para o português a legenda dessa narração.

Os licenciandos foram orientados a registrarem suas observações, individualmente e por escrito, ao assistirem à animação, considerando os seguintes parâmetros: conteúdo histórico, visões historiográficas, visões de ciência, conteúdo físico, possibilidade de utilização no ensino de Física. Seguindo aos registros individuais, estabeleceu-se discussão coletiva. A animação, por ter curta duração, cerca de quatro minutos e meio, foi repetida três vezes antes da discussão e exposição dos registros pela turma. Uma análise detalhada dos referidos registros será apresentada em seção posterior do presente trabalho.

\section{III.3 Momento 3 - Discussão coletiva da compilação de comentários individuais (síntese da turma)}

Os registros individuais realizados pelos licenciandos foram compilados de modo a configurarem uma síntese dos comentários realizados pela turma. Em aula subsequente ao contato com a animação e à atividade escrita individual, os licenciandos receberam cópias dessa compilação de comentários, identificada como "Análise da Animação The history of the barometer - turma 2017.2 HFC licenciatura" (Apêndice 1). A compilação foi realizada de modo a preservar a redação dos elementos contidos na atividade individual. Os licenciandos receberam, portanto, as observações expressas por todos os colegas da turma. Foi, então, realizada uma discussão coletiva dos elementos registrados na compilação, de modo a ressaltar os parâmetros citados previamente: conteúdo histórico, visões historiográficas, visões de ciência, conteúdo físico, possibilidade de utilização no ensino de Física.

\section{III.4 Momento 4 - Atividade de reelaboração do roteiro da animação digital pelos grupos}

Em aula subsequente, os licenciandos foram organizados em grupos com quatro componentes. Em seguida, receberam orientação sobre a atividade a ser realizada pelo grupo: "DESAFIO: Considerem os elementos identificados pela turma na análise da animação 'A história do Barômetro' e as discussões em aula sobre transposição didática da HFC. Recriem, quadro a quadro, um roteiro o mais adequado possível para a animação. Cada grupo receberá uma síntese dos comentários da turma e a legenda da animação".

O termo "legenda", citado no enunciado do desafio, refere-se à fala do narrador que descreve os episódios históricos apresentados na animação. Produzimos a legenda no formato SubRip (.srt) através do software de código aberto Subtitle Edit ${ }^{22}$. Os arquivos do tipo SubRip

22 Disponível gratuitamente em <http://www.nikse.dk/subtitleedit>. Acesso em: 04 jul. 2018. 
podem ser "lidos" pela maioria dos softwares de mídia e de edição de legendas, além de poderem ser reproduzidos pela maioria das Smart TVs, centrais de multimídia e dos aparelhos de DVD e BluRay. Esse tipo de arquivo pode ser editado no computador por meio de um simples editor de textos, como o bloco de notas, facilitando eventuais correções e impressão da legenda para análise. No editor de textos, as legendas são indicadas por números, seguidos pelos momentos iniciais e finais da exibição das legendas no vídeo (vide Apêndice 2).

Propôs-se que cada grupo recriasse a legenda da animação The history of the barometer (Apêndice 2), ou seja, recriasse o roteiro traduzido da animação, tendo como base as apreciações realizadas pela turma, compiladas e previamente discutidas coletivamente. A situação proposta era sensivelmente crítica, uma vez que não havia a possibilidade de mudar os quadros da animação, mas apenas a fala do narrador. Cada quadro dessa animação é composto por uma ou várias legendas, em intervalos de tempo bem definidos. Assim, os estudantes tinham diante de si o desafio de lidar com a limitação de intervalo de tempo e imagens já prontas. Cada grupo deveria refletir sobre os caminhos a serem tomados considerando que a animação recriada supostamente seria utilizada para fins didáticos.

Nesse processo de reelaboração do roteiro, diversos aspectos sobre a inserção didática da HFC, discutidos na etapa formativa da intervenção, viriam à tona (FORATO; PIETROCOLA; MARTINS, 2012). Precisariam ser avaliados aspectos como a extensão e a profundidade dos textos de cada quadro da animação, a quantidade de informações contempladas e a adequação da formulação discursiva. Era preciso, ainda, atentar para a falta de pré-requisitos do público-alvo da animação em relação aos conhecimentos físicos, históricos, epistemológicos e filosóficos. Que aspectos do roteiro gostariam de manter? O que consideravam relevante? O que seria desejável ou imprescindível alterar? Como fazê-lo? Era mesmo possível alterar certos aspectos, levando em conta o tempo previsto para cada legenda, as situações e os personagens mostrados? E quanto ao grau de complexidade daquilo que se desejava introduzir, como fazê-lo?

Cada grupo deveria apresentar o roteiro recriado. Além disso, explicitamente, cada grupo deveria indicar os objetivos didáticos da proposta, apontar os aspectos selecionados para reformulação e as dificuldades encontradas.

Os licenciandos já haviam sido avisados nas aulas anteriores de que haveria esse tipo de atividade, ou seja, a criação de novas legendas para inclusão em vídeos pré-existentes. Essa é uma prática um tanto comum nas mídias sociais, nas quais trechos famosos de determinados filmes são recriados, geralmente para fins de entretenimento. Uma das edições mais populares desse tipo remete a um trecho do filme "Der Untergand" (no Brasil, A Queda), mais especificamente, ao momento no qual é encenada a reação exaltada de Adolf Hitler ao ser avisado por seus subordinados sobre o avanço do exército inimigo. Há diversas edições desse trecho do filme, tanto em termos de legenda quanto de áudio, envolvendo temas como, 
por exemplo, a derrota do Brasil para a Alemanha na Copa do Mundo de Futebol de $2014^{23}$, a hipotética reprovação de Hitler no Exame Nacional do Ensino Médio (ENEM) ${ }^{24}$ e o seu hipotético descredenciamento de um programa de pós-graduação ${ }^{25}$.

A empolgação despertada na turma com a proposta dessa atividade sobre a animação digital pôde ser notada em atitude de um dos licenciandos em momentos subsequentes. Por iniciativa própria, um estudante trouxe à professora o trabalho que resolveu realizar: inseriu legendas, na referida cena do filme "A Queda", mostrando Hitler enfurecido ao dar-se conta das distorções nos livros didáticos a respeito do conteúdo histórico sobre vácuo e pressão atmosférica ${ }^{26}$. O resultado havia ficado tão interessante e divertido que a professora abriu espaço para a apresentação da produção do estudante à turma.

\section{Resultados obtidos nas etapas específicas sobre a animação na intervenção didática}

\section{IV.1 Comentários detalhados sobre a análise individual realizada pelos licenciandos}

Os registros escritos realizados individualmente pelos estudantes sobre a animação The History of the Barometer surpreenderam pelo nível de aprofundamento da análise face aos parâmetros sugeridos, pela diversidade de elementos e exemplos ilustrativos aludidos ${ }^{27}$.

Todos os aspectos citados a seguir provêm das anotações realizadas pelos licenciandos. Não foi nosso objetivo realizar uma análise quantitativa a respeito da incidência dos referidos comentários. A intenção, por outro lado, foi realizar uma compilação de comentários da turma (que seria utilizada em etapa posterior da intervenção) e tecer considerações sobre os referidos apontamentos.

Essa compilação (vide Apêndice 1) mostra que houve críticas ao título e ao enredo da animação. Apontou-se que esses elementos transmitem a ideia de que a descoberta do barômetro era um resultado inevitável, iniciado com a contestação do "horror ao vazio". O caminho percorrido pelos cientistas parece ter como objetivo chegar ao produto atual, o barômetro. Os pesquisadores parecem conhecer as respostas previamente aos estudos.

Em termos de fundamentos historiográficos, os licenciandos observaram alinhamento à História Whig e traços de anacronismo. Identificaram na animação vários elementos característicos desse tipo de narrativa, como a tendência a separar os personagens em certos e errados e a alusão ao ponto de vista do tempo presente como certo, em contraste com um pas-

\footnotetext{
${ }^{23}$ Disponível em: <https://www.youtube.com/watch?v=kxxww7L7HSY\&t=17s>. Acesso em: 01 jun. 2018.

${ }^{24}$ Disponível em: <https://www.youtube.com/watch?v=koyHQfFrzmU>. Acesso em: 01 jun. 2018.

${ }^{25}$ Disponível em: <https://www.youtube.com/watch?v=J4iW5iyfFAw>. Acesso em: 01 jun. 2018.

${ }^{26}$ Disponível em <https://youtu.be/BRSPMvHIo3M>. Acesso em: 25 ago. 2018.

27 A título de exemplificação dos registros individuais podemos citar alguns comentários: "Usa ideias posteriores para mostrar que Aristóteles estava errado"; "Cada um fez algo e ninguém fez em conjunto"; "Não cita que a ideia de substituir a água pelo mercúrio veio de Galileu"; "Torricelli não queria simplesmente mostrar a pressão atmosférica".
} 
sado equivocado. Segundo os estudantes, anacronicamente, a animação usa ideias posteriores a Aristóteles para mostrar que ele estava errado. Afirma que "felizmente" descobriu-se que Aristóteles estava errado a respeito da existência do vazio. $\mathrm{O}$ "horror ao vazio" é citado como dogma e apresentado no mesmo nível do senso comum. Dá a entender que o "horror ao vazio" não trazia explicações satisfatórias sobre os fenômenos naturais, ao afirmar que se passaram dois mil anos até que os questionamentos fossem "resolvidos". Em contraste com o "horror ao vazio", de acordo com a narrativa, a contestação iniciada por Galileu seria ciência de fato.

Os licenciandos usaram a expressão "simplificação" em referência ao modo como o "horror ao vazio" é explicado. Afirmaram que a animação não faz jus a essa teoria, não explica as ideias de Aristóteles e não demonstra o que significavam. Um dos licenciandos apontou que o curto tempo de duração da animação poderia ser a causa para tal nível de simplificação. Ainda como traços de anacronismo, os estudantes identificaram o uso do conceito de "pressão atmosférica" tal como o conhecemos atualmente. Segundo perceberam, a animação se refere ao "peso" do ar em sentido newtoniano, em época na qual Newton não havia produzido seus trabalhos.

Elemento característico de uma abordagem externalista foi identificado pelos estudantes na menção ao problema do bombeamento da água. A necessidade dos mineiros teria impulsionado os estudos científicos. Por outro lado, alguns estudantes consideraram que a animação realizou uma abordagem internalista, apenas citando quem fez o quê.

Em relação às visões de ciência, foi amplamente citado que uma postura empiristaindutivista permeia a animação. Segundo os licenciandos, esta mostra o experimento como fator decisivo, crucial para comprovação. O experimento do Puy-de-Dôme parece colocar um ponto final em questionamentos. A narrativa mostra que os personagens extraem conclusões tornadas óbvias pelos experimentos. Torricelli vê que a coluna de mercúrio é equilibrada pela pressão do ar. Pela observação, vê-se claramente a presença do vazio. Gasparo Berti assim descobre o "vácuo estável". A animação não considera que os resultados experimentais foram profundamente discutidos e objeto de controvérsias.

Segundo os estudantes, na animação os personagens surgem como mentores repentinos de experimentos e ideias pontuais, não havendo um processo associado a esses trabalhos. Carregando traços de História Pedigree, a animação traz Torricelli como "o cara" por pensar fora do convencional. A sentença "pensar fora da caixa, ou do tubo, pode ter um grande impacto" ressaltaria o individualismo. O experimento do Puy-de-Dôme é descrito como obra de Pascal, isto é, a paternidade do experimento é atribuída a um único indivíduo. Não há referência à atuação de Périer e ao seu grupo de colaboradores, os quais, a pedido de Pascal, fizeram o experimento.

Será, portanto, que a animação transmitiria uma visão de ciência individualista? Para a maior parte da turma, sim. Não há diálogo entre os pensadores. De acordo com os estudantes, em alguns momentos a atividade de um personagem coincide com a de outro, mas todas 
são essencialmente individuais. Ainda que em alguns casos haja discordância em relação a uma ideia anterior, a narrativa se passa como se cada personagem por si só acrescentasse mais um tijolo do conhecimento atual. Cada um fez algo e nada se fez em conjunto. A ciência é mostrada como um somatório de contribuições de gênios isolados. Para três estudantes, no entanto, a citação de vários personagens ao longo da animação daria ideia de cooperação. Um deles ressaltou, ainda, que essa cooperação parece produzir conhecimento em processo linear rumo ao produto final barômetro. À exceção de um único estudante, todos os outros apontaram que a citação de personagens e seus acréscimos de conhecimento, ou seja, uma descrição passo a passo de quem fez o que, indicaria linearidade. Apenas um estudante considerou que a animação não trazia uma visão de ciência linear por mencionar o "horror ao vácuo", o que indicaria ruptura.

Quanto ao conteúdo histórico, segundo os estudantes, alguns episódios citados pela animação não condizem com os registros históricos, havendo distorções e inconsistências. A narrativa faz parecer que a discussão sobre o "horror ao vazio" ficou estagnada de Aristóteles a Galileu. Ao contrário disso, lembraram os estudantes, houve questionamentos ao "horror ao vazio" anteriores ao problema de elevação da água. A narrativa cita que a "ideia de existir vácuo não estava sendo bem aceita". Essa afirmação seria de certa forma uma distorção, uma vez que a existência do vazio não estava mesmo sendo aceita. O "horror ao vazio" preponderava, inclusive após o experimento de Torricelli, na época de Pascal.

De acordo com os estudantes, na animação, os conhecimentos atribuídos a Galileu não representam adequadamente as visões do pesquisador sobre o assunto. Galileu considerava que a coluna de mercúrio se comportava tal como uma corda, podendo ser esticada até certo limite. Galileu considerava que a matéria resistia à formação de vazios extensos internos.

A narrativa apresentada, segundo os licenciandos, não leva em conta que os experimentos foram profundamente discutidos. Não registra dificuldades e hesitações dos pesquisadores. O experimento de Gasparo Berti é citado como "simples" e prova de um "vazio estável”. No entanto, Berti utilizou água e, por isso, precisou de um tubo muito longo, o que acarretou dificuldade de visualização do seu conteúdo interno. Como não havia como fazer um tubo tão longo de vidro, foi necessário usar um tubo de metal. Em tentativa de convencer que um espaço vazio de fato havia se formado acima do líquido, Berti colocou um sino nessa região e fê-lo badalar com a ajuda de um imã. Sua expectativa de que nenhum ruído seria ouvido foi frustrada.

Apesar de Galileu ser um personagem presente na animação, não há a sinalização de que a ideia de substituir água por mercúrio seria proveniente desse pesquisador. Passa-se da montagem de Berti para a montagem de Torricelli sem justificativas ou explicações. Os estudantes observaram com estranheza que Galileu, falecido em 1642, apareça na animação criticando a interpretação de Torricelli para o seu experimento, realizado em 1644, portanto, dois anos após a sua morte. 
Por omissão de contribuições antecedentes que influenciaram Torricelli, a animação transmite a impressão equivocada de que ele foi o primeiro a pensar (espontaneamente) que o ar tinha peso e exercia pressão. Sugere que Torricelli mediu a pressão atmosférica e concluiu definitivamente que a pressão do ar era responsável pela sustentação da coluna de mercúrio. Torricelli parece, na animação, discordar totalmente do horror ao vazio.

Os estudantes consideraram que a narrativa a respeito do trabalho de Torricelli não condiz com os registros históricos. Ele foi cauteloso ao se referir ao horror ao vazio. Em carta a Michelangelo Ricci, em descrição do seu experimento mais famoso, Torricelli disse que recorrer a essa causa era desnecessário, uma vez que a atuação do ar já explicava satisfatoriamente o fenômeno observado. $\mathrm{O}$ horror ao vácuo não foi definitivamente descartado pelo trabalho de Torricelli. Muito pelo contrário, permaneceu forte, tanto que o experimento do Puyde-Dôme, que é posterior, se insere na mesma linha de raciocínio no sentido de argumentar que a pressão do ar é responsável pela sustentação da coluna de mercúrio. Inserir-se na mesma linha de raciocínio não significa uma cooperação estreita entre Pascal e Torricelli. Em relato a Périer, Pascal se referiu ao "experimento ordinário do vácuo", sem citar o nome de Torricelli.

A animação mostra Blaise Pascal subindo a montanha para realizar o experimento com o mercúrio. No entanto, por motivos de saúde, Pascal não participou dessa empreitada. Seu cunhado Périer e uma equipe de colaboradores realizaram-no a pedido de Pascal. Segundo a narrativa, o objetivo de Pascal era comprovar a variação da pressão atmosférica com a altitude. Esse, no entanto, não era o objetivo de Pascal, e sim o seu ponto de partida. Pascal pretendia defender que a pressão do ar era responsável pela sustentação da coluna de mercúrio. Por isso, tomando como ponto de partida que a pressão caia com a altitude, esperava um decréscimo na coluna de mercúrio, o que satisfez suas expectativas.

Como se pode notar, a participação dos estudantes na análise da animação digital foi altamente qualificada. A compilação desses comentários serviu de base para que, em grupos, recriassem o roteiro da animação. A seção seguinte discute os resultados.

\section{IV.2 Comentários detalhados sobre os roteiros da animação reelaborados pelos grupos}

\section{Aspectos selecionados para reformulação e objetivos didáticos sugeridos}

De posse da síntese dos comentários da turma sobre a animação The history of the barometer (Apêndice 1), os licenciandos organizados em quatro grupos (A, B, C e D) se dedicaram ao desafio proposto (Apêndice 2). O primeiro grupo intitulou sua proposta como "Uma breve história do vácuo e da ideia de pressão do ar". O objetivo didático da proposta seria "discutir o contexto histórico do vácuo e a ideia de pressão do ar". Como aspectos selecionados para reformulação, o grupo indicou:

Alguns aspectos que tentamos observar foram os anacronismos, a distorção de alguns ocorridos históricos, individualismo, história whig etc. Tentamos focar no con- 
texto histórico, buscando evitar traços que consideramos ingênuos em termos de visão de ciência. (Grupo A)

O segundo grupo definiu como objetivo didático de sua proposta "tratar das discussões históricas acerca do vazio associando o desenvolvimento do seu estudo à compreensão sobre a pressão atmosférica". Manteve o título original da animação (“A História do Barômetro"), justificando que o barômetro seria objeto de estudo, por sua finalidade e seu funcionamento se relacionarem intrinsecamente a essas discussões. O grupo relacionou a percepção de determinadas concepções historiográficas a visões de ciência consideradas ingênuas, que desejavam evitar. Algumas alterações apontavam para o conteúdo histórico em si. Foram selecionados diversos aspectos para reformulação:

Procuramos desfazer a apresentação de personagens históricos como certos ou errados (história Whig) ou como grandes heróis e gênios inventores trabalhando isoladamente (hagiografia e individualismo), ressaltando as colaborações entre os personagens. Alguns pontos do texto [roteiro da animação original] exibiam anacronismo, como os "mineiros italianos" em um tempo onde a Itália ainda não era um país existente. Outros pontos [...] modificados foram a apresentação do Pascal subindo a montanha, onde decidimos o colocar apenas como portador da ideia de realizar tal experimento, [sobre a animação original apresentar] o Galileu como antagonista à ideia de o ar exercer peso, [a alteração foi realizada] removendo seu nome desta cena (o Galileu estudou sobre o ar e, diferente do que se apresenta no vídeo, era favorável à ideia de o ar exercer peso), $e$ [sobre a animação original apresentar] o Torriceli como comprovando a pressão atmosférica a realizar o experimento de Berti com mercúrio, [houve alteração] tendo em vista que tal discussão ainda se prolongou durante muito tempo. (Grupo B)

Ainda sobre os aspectos que desejaram modificar, o mesmo grupo citou:

As cenas com texto anacrônico onde aparecem os termos "pressão atmosférica" foram as que mais nos preocuparam, pois este é um termo para uma ideia recente se comparado às ideias desenvolvidas na época. (Grupo B)

O terceiro grupo (Grupo C) propôs um novo título para a animação: "Como se deu a construção do conceito de pressão atmosférica?”. Definiu como objetivos didáticos, apresentar alguns aspectos da história que levaram ao conceito de pressão atmosférica, tentando evidenciar mais rupturas e discordâncias na ciência. Foram objetivos explicitados pelo grupo ressaltar o caráter humano da ciência e a complexidade do processo de mudança de uma teoria vigente. Ao citar os aspectos selecionados para reformulação, o grupo mencionou História Whig, excesso de simplificações, anacronismo, História Pedigree, não humanização da ciência e situações não condizentes com os registros históricos. 
O quarto grupo (Grupo D) batizou a animação recriada como "Estudos sobre o vazio e a pressão atmosférica". Os objetivos didáticos elencados foram apresentar ideias e experimentos sobre a natureza do vazio e a pressão atmosférica. O grupo pretendeu abordar exemplos de cooperação na ciência, rupturas e paralelos entre ideias, com a finalidade de "trazer de forma sutil, pensamentos que desconstruam toda a premissa equivocada que é resultante de uma História da Ciência mal feita". Ao apresentar os aspectos selecionados para reformulação, o grupo manifestou a preocupação de ter o "enfoque principal [da animação original] alterado possibilitando uma forma adequada de exibi-lo, assim facilitando a retirada (dentro do possível) de erros segundo o que já vimos na disciplina até o momento”.

\section{Dificuldades identificadas pelos grupos}

O registro realizado pelo Grupo A acerca das dificuldades encontradas traz elementos interessantes para que possamos compreender como os futuros professores vivenciaram o desafio da transposição didática da HFC:

Sentimos dificuldades principalmente no começo, quando tivemos que pensar sobre o objetivo e tentar conciliar com o roteiro do vídeo buscando evitar os problemas apontados por nós mesmos no vídeo e na legenda. Outras dificuldades que encontramos foi para sincronizar as legendas com o vídeo, driblar os anacronismos forçados pela mídia visual e verificar as informações contidas no vídeo. Além disso, encontramos barreiras também para unir os textos com o nosso objetivo didático e colocar no vídeo. O que pudemos notar é que a maioria das dificuldades foi diminuindo à medida que avançávamos no novo roteiro, apesar de aparecer outras com as quais conseguimos contornar. (Grupo A, grifo nosso)

O Grupo B citou dificuldades notadas e explicou como tentou contorná-las:

O vídeo em si já traz bastante informação por meio de textos, e se torna incoerente exibir uma informação na legenda enquanto outra totalmente contrária está sendo exibida em imagens ou por escrito [legenda] no vídeo. Para amenizar tais incoerências, procurou-se manter ao máximo os diálogos originais, entretanto, realizando as modificações necessárias à transformação das ideias de comprovação em ideias de pesquisa e estudo, e as incoerências históricas em uma reapresentação da cena sob um novo contexto. (Grupo B)

O terceiro grupo (Grupo C) se expressou acerca de dificuldades que levaram a limitações no processo de transposição didática da HFC: “Adequar as falas às imagens, selecionar falas curtas que coubessem no tempo da legenda, e conseguir corrigir os erros de História e Filosofia da Ciência que detectamos no vídeo (só conseguimos corrigir parcialmente)". Segundo o quarto grupo (Grupo D), a tarefa de modificar o que criticaram não foi fácil. Ao ex- 
pressar quais foram as dificuldades notadas, o grupo admitiu: "Tudo, desde a escolha do enfoque, até a decisão do que manter e do que alterar na tentativa de manter coerente com o vídeo e com o tamanho da legenda".

\section{Edições realizadas}

Ao observarmos as legendas criadas pelos Grupos A, B, C e D (Apêndice 3), notamos alguns aspectos a comentar ${ }^{28}$.

Os primeiros segundos da animação original fazem referência a Aristóteles. Explicam rapidamente o "horror ao vácuo" e terminam com um juízo de valor sobre a mudança de visão a respeito da concepção aristotélica. Esse trecho corresponde às quatro primeiras legendas do roteiro da animação (Quadro 2). A ordem de exibição de cada legenda é indicada por um número entre colchetes.

Quadro 2 - As quatro primeiras legendas do roteiro original traduzido da animação.

[1] É conhecida a afirmação de Aristóteles: "A $\quad$ [3] porque a matéria em volta imediatamente o Natureza tem horror ao vácuo", preencheria.

[2] quando afirmou que não podia existir um verdadeiro vácuo, um espaço sem matéria.

[4] Felizmente, veio a saber-se que ele estava errado.

Os grupos iniciaram seus trabalhos mantendo as três primeiras legendas tal como na animação original. Todos os grupos identificaram características de História Whig e anacronismo na afirmação trazida pela quarta legenda. Decidiram substituí-la (a modificação realizada pelo Grupo C substituiu também a quinta legenda) conforme indica o Quadro 3.

Quadro 3 - Modificações indicadas pelos grupos para a legenda de número 4.

\begin{tabular}{cc}
\hline Grupo & Modificação da legenda de número 4 \\
\hline A & Mas esse era apenas um dos pensamentos da época. \\
B & Mas atualmente, acreditamos que as coisas não são bem assim. \\
C & Futuramente, veio a saber que foi contestado. Outros afirmaram que podia existir, mas com \\
muita dificuldade.
\end{tabular}

A necessidade de substituí-la foi tomada pelos Grupos A e C como oportuna para a indicação de que a convicção sobre a inexistência do vazio não era unânime. A alteração realizada foi interessante, ainda que as limitações de espaço não permitissem explorar tais pen-

\footnotetext{
${ }^{28}$ Como o tempo de exibição de cada legenda já está explicitado no texto do Apêndice 2, decidimos apresentar no Apêndice 3 as legendas criadas pelos grupos indicando apenas o número referente à sequência de exibição.
} 
samentos (dos atomistas, por exemplo). Inseriu-se, assim, a ideia de pluralidade de visões, não observada nessa passagem na animação original.

Já os Grupos B e D, escolheram como substitutas afirmações que reforçam a importância histórica do pensamento aristotélico sobre o vazio. Se por um lado tal escolha é interessante, por outro, a omissão de visões opostas pode transmitir a ideia de que a concepção aristotélica seguiu monoliticamente sem dissidências até a Revolução Científica (ou mesmo até os dias atuais, numa possível acepção literal da afirmação do Grupo B), o que não corresponde historicamente ao ocorrido.

Em sequência ao trecho sobre Aristóteles, a animação original apresenta uma brusca quebra de continuidade, partindo da "oportuna" rejeição à visão aristotélica ao barômetro (Quadro 4).

Quadro 1 - Sequência original (legendas 5 a 12) referente ao barômetro.

\begin{tabular}{|l|l|}
\hline $\begin{array}{l}\text { [5] O vácuo é um componente essencial do ba- } \\
\text { rômetro, }\end{array}$ & $\begin{array}{l}\text { [9] pode contribuir para furacões, tornados e } \\
\text { outros incidentes climáticos extremos. }\end{array}$ \\
\hline $\begin{array}{l}\text { [6] um instrumento para medir a pressão atmos- } \\
\text { férica. }\end{array}$ & $\begin{array}{l}{[10] \text { Um barômetro é um dos instrumentos mais }} \\
\text { essenciais }\end{array}$ \\
\hline $\begin{array}{l}\text { [7] Como a pressão atmosférica está ligada à } \\
\text { temperatura }\end{array}$ & $\begin{array}{l}\text { [11] para as previsões meteorológicas e para os } \\
\text { cientistas. }\end{array}$ \\
\hline [8] e depressa se transforma nela, & $\begin{array}{l}\text { [12] Como funciona um barômetro e como é que } \\
\text { foi inventado? }\end{array}$ \\
\hline
\end{tabular}

O enredo um tanto quanto confuso da animação original se estabelece devido a lacunas e à falta de conexões mínimas, que poderiam ser evitadas por uma legenda do tipo: "as discussões sobre a existência do vazio se relacionaram ao desenvolvimento do conceito de pressão atmosférica e à proposta de um instrumento para medi-la".

O Grupo A parece ter ensaiado algo nesse sentido, embora de forma pouco clara, ao afirmar nas legendas 5 e 6: "O vácuo é um conceito essencial para se entender a pressão atmosférica, que possui grande importância na sociedade". O enredo estabelecido pela animação original foi mantido pelo Grupo B para essa sequência de legendas, sem alterações. $\mathrm{O}$ Grupo C não foi bem sucedido nas alterações dessas passagens, construindo um enredo também confuso, com acentuadas lacunas que comprometiam seu entendimento conforme exposto a seguir:

Depois de muita discussão, cientistas diziam que o ar tinha peso e exercia pressão. Mas a explicação para a sustentação do líquido não era unânime. Já que esse horror ao vazio poderia talvez variar com a altura. Hoje, nós temos explicações totalmente diferentes. E graças a diversos debates históricos, conseguimos instrumentos 
de medida daquilo que chamamos hoje de "Pressão atmosférica". (Grupo $\mathrm{C}$, legendas 6 a 11)

Pode-se perceber que faltam conexões entre a consideração sobre Aristóteles e a afirmação sobre o ar ter peso e exercer pressão (legenda 6). Não se pode compreender a que fenômeno de sustentação de líquido se refere a afirmação contida na legenda 7, bem como são obscuras as explicações citadas nas legendas 8 e 9 . O texto proposto pelo Grupo $\mathrm{C}$ oscila entre referências ao vazio e à pressão, sem esclarecer possíveis conexões entre os fenômenos. Ademais, as afirmações contidas nas legendas 10 e 11 parecem sinalizar que as discussões tinham como objetivo final a obtenção de um instrumento de medida.

O Grupo A também teve problemas quanto à continuidade da narrativa, pois nas legendas imediatamente subsequentes à sequência modificada sobre Aristóteles observa-se uma quebra brusca de pensamento: "Temos aqui um modelo ilustrativo de barômetro. Hoje é bastante aceito que o ar exerce pressão sobre os corpos, incluindo líquidos". Assim, passa-se repentinamente da questão do vácuo na Antiguidade ao barômetro e à ideia de pressão do ar. Além disso, a legenda sinaliza certa visão atual sobre a pressão do ar. Permanece a dúvida, da legenda 6 até a legenda 11, sobre se essa visão foi ou não diferente no passado.

$\mathrm{Na}$ animação original, após breves referências à utilidade do barômetro, aparecem os trechos transcritos no Quadro 5.

Quadro 5 - Sequência original (legendas 12 a 16).

\begin{tabular}{|l|l|}
\hline $\begin{array}{l}\text { [12] Como funciona um barômetro e como é que foi in- } \\
\text { ventado? }\end{array}$ & $\begin{array}{l}{[15] \text { no que se referia à impossibilidade }} \\
\text { do vácuo, }\end{array}$ \\
\hline [13] Levou algum tempo. & $\begin{array}{l}{[16] \text { parecia ser verdade na vida quoti- }} \\
\text { diana, }\end{array}$ \\
\hline $\begin{array}{l}\text { [14] Porque a teoria de Aristóteles e de outros filósofos } \\
\text { da Antiguidade, }\end{array}$ & \\
\hline
\end{tabular}

Os Grupos A e B mantiveram esse trecho do enredo tal qual na animação original. Essa sequência, no entanto, pode transmitir a impressão de antecipação do futuro na medida em que havia um percurso a ser transposto até certo destino final premeditado de criação do instrumento barômetro. "Levou algum tempo", mas, enfim, o ponto de chegada foi atingido. Dessa forma, Aristóteles e a impossibilidade do vazio aparecem como obstáculos a serem transpostos para que o surgimento do barômetro fosse possível, no caso dos Grupos A e B.

A ideia questionável transmitida pela animação original e mantida pelos referidos grupos diz respeito a conceber que para chegar à ideia de pressão atmosférica e ao barômetro seria necessário aceitar a existência do vazio, negando o "horror ao vácuo". Essa ideia é abalada por exemplos históricos como o pensador René Descartes. O (provável) mentor do experimento do Puy-de-Dôme, intrinsecamente relacionado ao desenvolvimento do barômetro, 
aceitava a ideia de pressão atmosférica e rejeitava a existência do vazio (MARTINS, 1989a) ${ }^{29}$.

O Grupo D, tal como os Grupos A e B, também optou pela manutenção desse trecho do enredo, trocando apenas o questionamento apresentado na legenda 12 por: "e como os estudos sobre o vazio se desenvolveram? Levou algum tempo [e reproduz em seguida o trecho supracitado obre Aristóteles...]". Já o Grupo C também alterou o questionamento: "Mas como se deu o processo de construção desse conceito atual [pressão atmosférica]? Não foi nada simples. Aristóteles dizia [...]. [descreve a explicação para o movimento de objetos lançados com base na inexistência do vazio]. E muitos concordavam plenamente. Tal explicação perdurou muito tempo". Nesse caso novamente parece que a visão aristotélica representou um obstáculo ao avanço do conhecimento.

Como seria possível evitar a mensagem inadequada transmitida pela animação original?

Uma afirmação simples que estabelece conexões, mas não relações do tipo causa e consequência seria mais adequada. Por exemplo: "O surgimento do barômetro está relacionado a discussões sobre o vazio". A referência a Aristóteles poderia ocorrer como exemplo de discussão, mas não como um empecilho, nem de modo a se equiparar ao senso comum, tal como indica a expressão "parecia ser aceita na vida quotidiana". A teoria de Aristóteles no que se referia à impossibilidade do vazio era sofisticada e parte essencial da visão de mundo aristotélica. Relacionava-se à explicação de diversos fenômenos ainda no século XVII. A legenda da animação original segue conforme mostra o Quadro 6.

Quadro 6 - Sequência original (legendas 17 a 21).

\begin{tabular}{|l|l|}
\hline $\begin{array}{l}\text { [17] pouca gente pensou em pôr isso em questão } \\
\text { durante quase 2000 anos }\end{array}$ & $\begin{array}{l}{[20] \text { enfrentaram um problema grave quando }} \\
\text { perceberam que as suas bombas }\end{array}$ \\
\hline $\begin{array}{l}{[18] \text { - até que a necessidade levantou o pro- }} \\
\text { blema. }\end{array}$ & $\begin{array}{l}\text { [21] não conseguiam elevar a água a mais do que } \\
\text { a 10,3 metros de altura. }\end{array}$ \\
\hline $\begin{array}{l}\text { [19] No início do século XVII, os mineiros itali- } \\
\text { anos }\end{array}$ & \\
\hline
\end{tabular}

O Grupo B manteve esse trecho do enredo à exceção da exclusão do termo "italianos", pois, conforme citamos, o grupo considerou anacrônica a referência à nacionalidade uma vez que na época a Itália ainda não existia como país. Os Grupos A, C e D retiraram a afirmação contida na legenda 18. Essa exclusão é um ponto significativo porque a legenda original parece transmitir a impressão de que quando surgiu a "necessidade" (antes inexisten-

29 O exemplo de Descartes, embora contido na narrativa histórica indicada aos estudantes para leitura (FONSECA et al., 2017), não foi tomado pelos grupos para questionamento do roteiro da animação. Uma análise detalhada sobre os episódios históricos citados nessa seção pode ser consultada no trabalho realizado pelo historiador da ciência Roberto de Andrade Martins (1989a). 
te?!) finalmente o caminho correto se mostrou.

O Grupo A propôs alterações adicionais. Enfatizou a importância dessa temática na História da Ciência, ao citar que nesses dois mil anos muitos pensadores se envolveram nas discussões sobre o vazio, realizando experimentos reais e imaginários. Preocupou-se em sinalizar que ambas as vertentes a favor e contra o vazio receberam contribuições. Em referência ao problema enfrentado pelos mineiros, o grupo decidiu adequar a unidade de medida ao contexto da época e utilizou "toesas" em lugar de metros. A alteração pode ser interessante no sentido de estimular a percepção de que no passado outras unidades de medida eram usadas. Por outro lado, no contexto educacional, pode haver dificuldade para que os alunos da educação básica imaginem as situações narradas, uma vez que não estão habituados a essa unidade. Em outro trecho da animação recriada, o grupo complementou a referência a toesas com uma conversão para parâmetros atuais, o que pode ser mais adequado: "Estima-se que a coluna estabilizou aproximadamente em $76 \mathrm{~cm}$ em medidas atuais".

Em seguida à menção do problema enfrentado pelos mineiros, a animação faz referência à explicação trazida na época por Galileu Galilei (Quadro 7).

Quadro 7 - Sequência original (legendas 22 a 27).

\begin{tabular}{|l|l|}
\hline $\begin{array}{l}\text { [22] Alguns cientistas, nessa época, incluindo } \\
\text { um tal Galileu Galilei, }\end{array}$ & $\begin{array}{l}\text { [25] Mas essa força era limitada e só podia ele- } \\
\text { var 10,3 metros de água. }\end{array}$ \\
\hline [23] propuseram que retirar o ar do tubo & [26] Porém, a ideia de existir um vácuo \\
\hline $\begin{array}{l}\text { [24] era o que fazia com que a água substituísse } \\
\text { [27] ainda era considerada controversa. }\end{array}$ & [2] \\
\hline
\end{tabular}

Os Grupos A, B e D não fizeram modificações nesse trecho. Permaneceu a obscura referência à interpretação de Galileu para o não funcionamento das bombas dos mineiros. $\mathrm{O}$ Grupo C, por sua vez, decidiu refazer essa passagem no enredo original da seguinte forma:

Alguns cientistas, nessa época, incluindo Galileu Galilei, propuseram que retirar o ar do tubo fazia a água se esticar para ocupar o espaço vazio. Mas esse esticamento era limitado e só podia elevar 10,3 metros de água. Porém, a ideia de existir um vazio ainda era controversa. (Grupo C, legendas 22-27)

O Grupo C, portanto, tentou esclarecer o porquê da limitação segundo Galileu. O pesquisador considerava a aversão da natureza à formação de vazios extensos. Para ele, a água se elevava devido à "força do vácuo". As porções de matéria tendiam a ficar juntas de forma a evitar o vazio. No entanto, havia um ponto crítico - pouco mais de $10 \mathrm{~m}$ - no qual a coluna de água se rompia, sendo impossível "esticá-la" além desse limite. A narrativa proposta pelo Grupo $\mathrm{C}$, além de elucidativa, ajustou-se adequadamente à mídia visual, permitindo um avanço de qualidade nesse trecho da animação digital. 
Em seguida à referência a Galileu, a animação original apresenta o experimento de Gasparo Berti, encerrando a discussão sobre a existência do vazio, e a investigação de Torricelli, que estaria direcionada à sustentação da coluna de líquido (Quadro 8).

Quadro 2 - Sequência original (legendas 28 a 45).

\begin{tabular}{|l|l|}
\hline $\begin{array}{l}\text { [28] A polêmica sobre a teoria pouco ortodoxa } \\
\text { de Galileu }\end{array}$ & $\begin{array}{l}{[37] \text { Berti tinha conseguido criar diretamente um }} \\
\text { vácuo estável. }\end{array}$ \\
\hline $\begin{array}{l}\text { [29] levou Gasparo Berti a fazer uma experiên- } \\
\text { cia simples mas brilhante }\end{array}$ & $\begin{array}{l}{[38] \text { Mas, apesar de ter sido demonstrada a pos- }} \\
\text { sibilidade de um vácuo, }\end{array}$ \\
\hline [30] para demonstrar que era possível. & $\begin{array}{l}{[39] \text { nem todos ficaram satisfeitos com a ideia de }} \\
\text { Galileu }\end{array}$ \\
\hline [31] Encheram um tubo comprido com água & $\begin{array}{l}\text { [40] de que esse vácuo estivesse a exercer algu- } \\
\text { ma força misteriosa, }\end{array}$ \\
\hline $\begin{array}{l}\text { [32] e colocaram-no numa bacia baixa com as } \\
\text { duas extremidades mergulhadas. }\end{array}$ & [41] embora finita, sobre a água. \\
\hline $\begin{array}{l}\text { [33] Depois abriram uma das extremidades do } \\
\text { tubo }\end{array}$ & $\begin{array}{l}\text { [42] Evangelista Torricelli, pupilo e amigo de } \\
\text { Galileu, }\end{array}$ \\
\hline [34] e despejaram água para a bacia & $\begin{array}{l}\text { [43] decidiu olhar para o problema por um ângu- } \\
\text { lo diferente. }\end{array}$ \\
\hline $\begin{array}{l}\text { [35] até que o nível da água que se manteve no } \\
\text { tubo ficou a 10,3 metros, }\end{array}$ & $\begin{array}{l}\text { [44] Em vez de se concentrar no espaço vazio no } \\
\text { interior do tubo, interrogou-se: }\end{array}$ \\
\hline $\begin{array}{l}\text { [36] com um espaço no cimo, sem que tenha } \\
\text { entrado nenhum ar no tubo. }\end{array}$ & $\begin{array}{l}\text { [45] Que outra coisa poderá estar a influenciar a } \\
\text { água? }\end{array}$ \\
\hline
\end{tabular}

A menção ao experimento de Berti é interessante, uma vez que este, via de regra, está ausente nos livros didáticos, os quais costumam trazer o experimento de Torricelli sem o seu antecedente com água. No entanto, deve-se observar que a animação traz distorções graves tantos em termos da narrativa, quanto no que se refere ao aspecto visual dessa passagem.

Historicamente, o experimento de Berti foi realizado com um tubo de chumbo, uma vez que não havia como confeccionarem um tubo de vidro de pelo menos dez metros de altura. A animação, no entanto, de modo inadequado traz um quadro com Berti realizando o experimento com um tubo cujo conteúdo é visível (Fig. 3). Tem-se a impressão de que o tubo usado por Berti seria de vidro, o que não condiz com os registros históricos. 


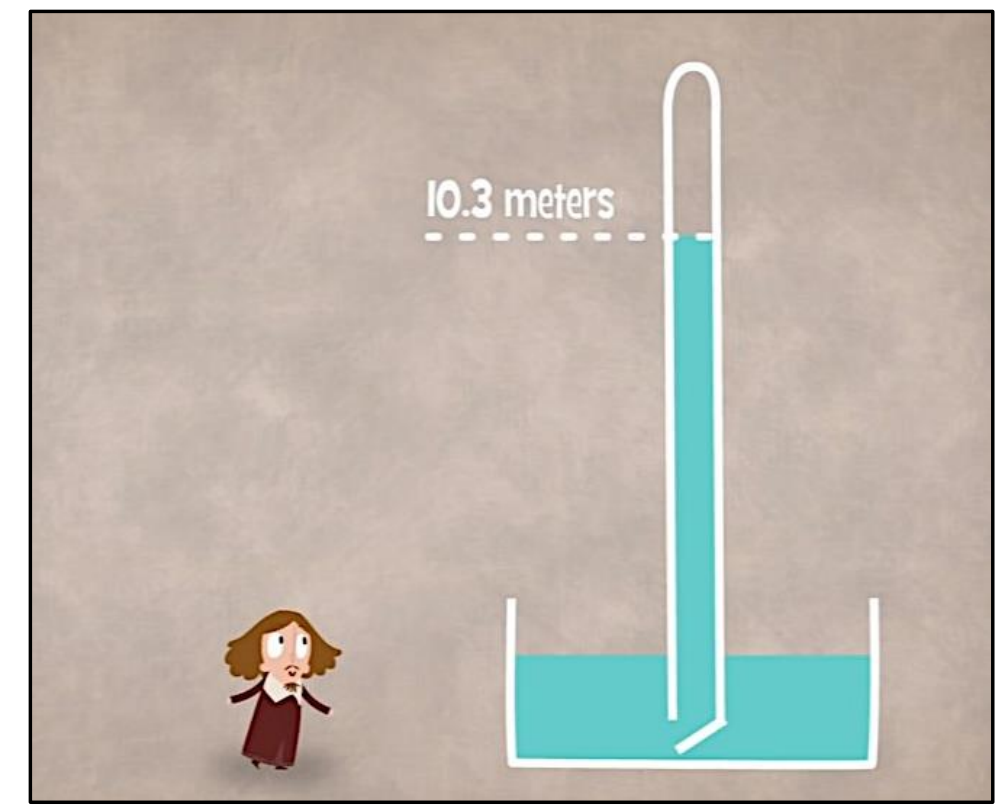

Fig. 3 - Quadro da animação tratando do experimento de Berti.

Fonte: Imagem obtida pelos autores por captura de tela.

Adicionalmente a este aspecto, outra discrepância em relação aos registros históricos se descortina na animação original. Afirma-se que "Berti tinha conseguido criar diretamente um vácuo estável”. Por omissão da argumentação empírica de Berti em defesa de que o alto do tubo estava vazio, bem como pelo desenho apresentado, tem-se a impressão de que o pesquisador visualmente mostrou o vácuo e esse foi aceito de forma indubitável. Assim, os questionamentos posteriores supostamente residiriam sobre a sustentação do líquido, enquanto que o vazio teria sido inequivocamente demonstrado. São elementos típicos de uma narrativa empirista-indutivista. Mais uma vez, os registros históricos contradizem esse cenário. As discussões sobre o vazio prosseguiram após o experimento de Berti.

O Grupo D não propôs alterações para as referências da animação original ao experimento de Berti. Por outro lado, os outros grupos tentaram reverter alguns problemas. $\mathrm{O}$ Grupo A não se referiu a Berti nominalmente. Por outro lado, descreveu o experimento histórico indicando adequadamente o material do tubo e o prosseguimento da controvérsia, pois "apenas isso não foi suficiente para convencer todos os pensadores da época de que ele [o vácuo] existia e/ou exercia alguma ação, mesmo que finita, sobre a água [...]" [legendas 38 a 41]. As distorções foram também objeto de alterações realizadas pelo Grupo B: "Berti tinha conseguido criar provavelmente um vácuo na parte superior do tubo. Entretanto, não era possível enxergar a altura da água e o vácuo [...] [legendas 37 a 38].”.

O Grupo C preocupou-se em sinalizar que o conteúdo do tubo não era visível ${ }^{30}$. Diante dessas circunstâncias, o grupo registrou que Berti, na tentativa de evidenciar que o tubo

${ }^{30} \mathrm{O}$ grupo se equivocou ao dizer que o tubo era de cobre, quando na realidade era de chumbo. 
estava vazio, havia se valido da ideia de que o som precisava de matéria para se propagar: "Encheram com água um enorme tubo de cobre, com um sino dentro, no topo, e colocaram num tonel com água. [...]. [...] Eles tocaram o sino do topo e não o ouviram"31. A narrativa proposta pelo grupo mostra que mesmo assim não houve plena aceitação do resultado.

Como se pode notar, os três grupos que propuseram alterações na passagem sobre Berti tiveram como foco as dificuldades na realização do experimento (por exemplo, o tubo de metal) e a não unanimidade quanto à aceitação da existência do vazio. Esses aspectos significativos, ausentes na animação original, permitem conectar o experimento de Berti às investigações de Torricelli.

A animação original afirma que Torricelli decidiu fazer o experimento de Berti com mercúrio, o que tornou o experimento mais compacto. De fato, o experimento se tornou portátil, mas não era somente isso que estava em jogo (legendas 61 a 63). Como bem destacou o Grupo C: "A grande vantagem desse experimento não era só o tamanho, mas permitia ver dentro do tubo, o que não era possível com tubo metálico" (legendas 62 e 63). Com a substituição da água pelo mercúrio, o conteúdo do tubo passou a ser visível. Isso era muito significativo no contexto de continuidade das investigações sobre o vazio, das quais Torricelli participou, uma vez que a controvérsia não havia sido encerrada pelo experimento de Berti. Era desejável visualizar o conteúdo do tubo.

Somente o Grupo D não deu destaque explícito a essa conexão em termos das intenções investigativas de Torricelli. Já o Grupo C enfatizou a continuidade: "Evangelista Torricelli, aluno de Galileu, decidiu investigar mais o experimento proposto por Berti. Se concentrou na parte de cima do tubo, mas também interrogou-se: O que mais poderia sustentar a água?" (legendas 42 a 45). O Grupo B destacou que Torricelli se preocupava em discutir sobre o vazio no tubo, além de investigar a sustentação na coluna de líquido. O Grupo A também transmitiu essa percepção ao indicar que era possível discutir algo além do vácuo no experimento realizado por Torricelli.

A influência de Galileu em relação a Torricelli foi lembrada nas animações recriadas pelos Grupos A, C e D, os quais inseriram a informação (não presente na versão original) de que a troca da água pelo mercúrio teria sido sugestão de Galileu.

$\mathrm{Na}$ animação original temos a seguinte narrativa para as investigações realizadas por Torricelli (Quadro 9).

\footnotetext{
${ }^{31} \mathrm{O}$ grupo se equivocou ao dizer que o pesquisador confirmou sua expectativa. $\mathrm{O}$ sino foi badalado e o som ouvido.
} 
Quadro 3 - Sequência original (legendas 42 a 62)

\begin{tabular}{|l|l|}
\hline $\begin{array}{l}\text { [42] Evangelista Torricelli, pupilo e amigo de Ga- } \\
\text { lileu, }\end{array}$ & $\begin{array}{l}\text { [53] O nível da água no tubo diminui até que } \\
\text { as pressões estejam iguais, }\end{array}$ \\
\hline $\begin{array}{l}\text { [43] decidiu olhar para o problema por um ângulo } \\
\text { diferente. }\end{array}$ & $\begin{array}{l}{[54] \text { o que acontece quando a água está a 10,3 }} \\
\text { metros. }\end{array}$ \\
\hline $\begin{array}{l}\text { [4] Em vez de se concentrar no espaço vazio no } \\
\text { interior do tubo, interrogou-se: }\end{array}$ & {$[55]$ Esta ideia não foi aceita facilmente, } \\
\hline $\begin{array}{l}\text { [45] "Que outra coisa poderá estar influenciando a } \\
\text { água?" }\end{array}$ & {$[56]$ porque Galileu e outros tinham pensado } \\
\hline $\begin{array}{l}\text { [46] Porque a única coisa em contato com a água } \\
\text { era o ar em volta da bacia. }\end{array}$ & $\begin{array}{l}\text { [57] que o ar atmosférico não tinha peso e } \\
\text { não exercia pressão. }\end{array}$ \\
\hline $\begin{array}{l}\text { [47] Ele pensou que a pressão do ar era a única } \\
\text { coisa que podia estar impedindo }\end{array}$ & $\begin{array}{l}\text { [58] Torricelli resolveu repetir a experiência } \\
\text { de Berti }\end{array}$ \\
\hline [48] que o nível da água no tubo caísse ainda mais. & {$[59]$ com mercúrio em vez de água. } \\
\hline $\begin{array}{l}\text { [49] Percebeu que a experiência não era somente } \\
\text { uma forma de criar o vácuo, }\end{array}$ & $\begin{array}{l}\text { [60] Porque o mercúrio era mais denso, caía } \\
\text { mais do que a água }\end{array}$ \\
\hline [50] mas funcionava como um equilíbrio & $\begin{array}{l}\text { [61] e a coluna de mercúrio elevava-se apenas } \\
\text { a 76 centímetros de altura. }\end{array}$ \\
\hline $\begin{array}{l}\text { [51] entre a pressão atmosférica sobre a água, no } \\
\text { exterior do tubo, }\end{array}$ & $\begin{array}{l}\text { [62] Isto permitiu que Torricelli tornasse o } \\
\text { instrumento mais compacto, }\end{array}$ \\
\hline [52] e a pressão da coluna de água dentro do tubo. & \\
\hline
\end{tabular}

As alterações realizadas pelos grupos em suas propostas foram variadas. Os Grupos $\mathrm{A}, \mathrm{B}$ e $\mathrm{C}$ se preocuparam com o tom assertivo dessas passagens.

O Grupo A trouxe elementos não contemplados na animação original como as dúvidas expressadas por Evangelista Torricelli em carta a Michelângelo Ricci sobre a sustentação da coluna de mercúrio. O grupo reescreveu, então: "Com base em uma carta de Torricelli ao seu amigo Ricci observamos [...] Que outra coisa poderá estar influenciando a água? [...] Ele pensou que o ar poderia influenciar no experimento. Sendo assim, o ar estaria realmente exercendo pressão sobre a água?" (legendas 42 a 47).

Mais adiante, nas legendas 52 a 55, o grupo explicou a hipótese do equilíbrio pensada por Torricelli e ressaltou que o pesquisador não descartou totalmente o horror ao vácuo: "Ele percebeu que apenas isso poderia ser suficiente para explicar o fenômeno. Todavia, nunca abandonou o pensamento que prevalecia. Tais questões o acompanham durante toda a carta" (legendas 48 a 50). A intenção do grupo, nesse sentido, foi ressaltar que para Torricelli a explicação com base na pressão do ar era suficiente. A redação sugerida pelo grupo poderia ser mais clara no sentido de trazer à tona o que Torricelli expõe a Ricci: ele não estava derrubando o "horror ao vácuo". Por simplicidade, não era necessário recorrer a essa hipótese. 
O Grupo C manifestou a mesma preocupação de evitar o tom de constatação da animação original, substituindo-o pela interpretação de Torricelli, permeada por hesitação e dúvida: "O que mais poderia sustentar a água? Torricelli considerou que o ar em volta do tonel poderia ser essa influência. Mas ficou bastante confuso com as possibilidades, já que o peso do ar não excluiria o horror ao vazio, amplamente aceito na época" (legendas 46 a 49).

O Grupo D não realizou alterações no sentido proposto pelos demais grupos para essas passagens da animação original. Por outro lado, agregou um elemento não pensado pelos outros grupos. Tanto na animação original, como nas propostas criadas pelos Grupos A, B e C, não há antecedentes para a ideia de pressão do ar. A animação original parece atribuir a ideia de pressão do ar a Torricelli, ao afirmar que "Galileu e outros tinham pensado que o ar atmosférico não tinha peso e não exercia pressão". Algo semelhante é dito pelo Grupo B, que apenas tirou a alusão explícita a Galileu. Já os Grupos A e C excluíram o comentário sobre a visão de "Galileu e outros" e não fizeram qualquer referência a respeito de considerações sobre $\mathrm{o}$ ar antecedentes a Torricelli.

No entanto, o pensamento de que o ar poderia estar exercendo pressão sobre a água não provinha de Torricelli, mas sim havia sido proposto anteriormente. Partindo de textos de Arquimedes, Simon Stevin já havia afirmado que os corpos imersos na água eram pressionados por todos os lados. Isaac Beeckman, discípulo de Stevin, considerou por analogia que no ar pudesse ocorrer o mesmo. A matéria seria empurrada pelo ar em direção aos espaços vazios. Isso ocorreria, por exemplo, em bombas d'água, segundo Beeckman. Comuns na época, esses mecanismos eram até então explicados com base no "horror ao vazio". Tomando como base esses antecedentes, o Grupo D redigiu que a ideia de pressão do ar tinha uma inspiração: "Evangelista Torricelli, aluno e amigo de Galileu, decidiu olhar para o problema pela visão de Isaac Beeckman, que fez uma comparação, assim como a água pressionava tudo imerso nela, o ar deveria comportar-se assim também" (legendas 42 a 46).

A animação original traz o que seria um experimento decisivo conduzido por Torricelli no sentido de eliminar a explicação de Galileu para a sustentação da coluna de líquido (Quadro 10).

Quadro10 - Sequência original (legendas 63 a 69).

\begin{tabular}{|l|l|}
\hline $\begin{array}{l}\text { [63] Mas comprovou a sua ideia de que o peso } \\
\text { era o fator decisivo. }\end{array}$ & [67] o vácuo maior, no segundo tubo, \\
\hline $\begin{array}{l}\text { [64] Numa variante da experiência usou dois } \\
\text { tubos }\end{array}$ & $\begin{array}{l}\text { [68] devia exercer maior sucção e elevar o mercú- } \\
\text { rio mais alto. }\end{array}$ \\
\hline $\begin{array}{l}\text { [65] em que um deles tinha uma grande bolha } \\
\text { no topo. }\end{array}$ & $\begin{array}{l}\text { [69] Mas o nível em ambos os tubos manteve-se o } \\
\text { mesmo. [grifos nossos] }\end{array}$ \\
\hline $\begin{array}{l}\text { [66] Se a interpretação de Galileu estivesse } \\
\text { correta, }\end{array}$ & \\
\hline
\end{tabular}


À exceção do Grupo D, todos os demais grupos retiraram a afirmação tipicamente empirista-indutivista de que o experimento seria comprobatório da hipótese do peso do ar responsável pela sustentação da coluna de mercúrio. O Grupo A registrou-o, por outro lado, como mais uma oportunidade investigativa de relevância para as discussões na época. O Grupo $\mathrm{C}$ registrou que, ao realizar o experimento, Torricelli estava "tentando argumentar contra o horror ao vazio". Já o Grupo B, afirmou que o resultado do experimento "reforçou" a ideia sobre a atuação do peso do ar.

O Grupo A trocou o adjetivo "correta" por "coerente", em referência à possibilidade (não ocorrida) de um eventual resultado favorável à interpretação de Galileu: "Se a interpretação de Galileu fosse coerente". Já o Grupo B manteve o adjetivo "correto", mas não afirmou que a interpretação de Galileu estava em jogo, mas sim o "horror ao vazio", que poderia estar "correto" se a coluna fosse maior no tubo com bulbo. O mesmo tom foi dado pelo Grupo C, que também excluiu o nome de Galileu e se referiu ao questionamento da explicação de sustentação interna.

A animação original, apesar de destacar o experimento com o tubo com bulbo superior como decisivo, prossegue ainda com o que seria o ponto final na controvérsia (Quadro 11).

Quadro 4 - Sequência original (legendas 70 a 73).

[70] O apoio final para a teoria de Torricelli apareceu através de Blaise Pascal

[72] e demonstrou que o nível de mercúrio [71] que levou um tubo de mercúrio para o alto de uma montanha descia

[73] quando a pressão atmosférica diminuía com a altitude.

Os estudantes haviam estudado em aula a carta de Florin Périer ao seu cunhado, o pesquisador Blaise Pascal, descrevendo a realização do experimento no Puy-de-Dôme. Em decorrência do estudo contextualizado do documento histórico, todos os grupos realizaram modificações nessa passagem. À exceção do Grupo B, todos os outros destacaram que Florin Périer, a pedido de seu cunhado Blaise Pascal, havia realizado o experimento. Corrigindo a animação, portanto, os Grupos A, C e D não afirmaram que Pascal realizou o experimento. Trazendo mais alguns elementos de contextualização, os grupos A e D, indicaram o caráter coletivo do experimento uma vez que Périer subiu a montanha acompanhado por uma comitiva de testemunhas. O Grupo D lembrou, ainda, que a inspiração para o experimento havia partido de René Descartes.

Outros aspectos chamaram a atenção dos licenciandos. A expressão "apoio final" mereceu a atenção dos grupos. O Grupo D retirou o termo "final”, registrando o experimento no Puy-de-Dôme somente como um "apoio para a teoria de Torricelli". De acordo com as 
redações transcritas a seguir, propostas pelos Grupos C e D, respectivamente, o experimento não pôs fim à controvérsia:

Apesar disso, mesmo com tantas observações e argumentos que corroboraram com a teoria da "Pressão Atmosférica", as investigações continuaram até que o horror ao vácuo foi perdendo seguidores. Isso mostra o quanto é trabalhoso mudar uma forte teoria vigente. (Grupo $\mathrm{C}$, legendas 79-83)

Após tudo isso a ideia de pressão atmosférica não conseguiu tantos adeptos e só veio ser aceita futuramente, de forma natural e gradativa e a ideia do "horror ao vazio" sem ter a necessidade de ser refutada. Os argumentos empíricos não sustentavam apenas as ideias de Torricelli, mas também a argumentação oposta, que continuou forte. (Grupo D, legendas 74-78)

Pode-se notar, assim, redações que explicitam o caráter lento das rupturas na construção do conhecimento científico, bem como se opõem a uma perspectiva empiristaindutivista acerca dos episódios históricos abordados.

O Grupo A lembrou que, para comparação, algumas montagens do experimento não foram carregadas para a montanha. $\mathrm{O}$ grupo não destacou explicitamente as expectativas que fundamentavam a realização do experimento, registrando apenas o resultado: "À medida que subiam perceberam que a coluna de mercúrio variava com a altura". Já o Grupo D destacou que havia uma intenção na realização do experimento: "para mostrar que o nível de mercúrio variava de acordo com a altitude". O caráter interpretativo e as hipóteses que orientavam a realização do procedimento transparecem nas redações propostas pelos Grupos B e C:

[...] e verificar o quanto o nível de mercúrio descia relacionando isto à pressão atmosférica que em teoria diminuiria com a altitude. (Grupo B, legendas 72-73, grifos nossos)

[...] para ver se o nível caía ao longo da subida, já sabendo que a pressão do ar diminuía com a altitude. E as expectativas do cunhado, Blaise Pascal, foram observadas”. (Grupo C, legendas 71-73, grifos nossos)

A finalização da animação original destaca a utilidade do barômetro e atribui sua invenção ao questionamento de "dogmas", em referência ao "horror ao vazio". Utilizando um trocadilho, elogia Torricelli por ser "fora da caixa", ou "fora do tubo". O Grupo B manteve a referida redação original. 
Quadro 12 - Sequência original (legendas 74 a 83).

\begin{tabular}{|l|l|}
\hline $\begin{array}{l}\text { [74] Os barômetros de mercúrio, } \\
\text { baseados no modelo original de } \\
\text { Torricelli, }\end{array}$ & $\begin{array}{l}\text { [75] mantiveram-se uma das formas habituais de medir a pres- } \\
\text { são atmosférica até 2007, }\end{array}$ \\
\hline $\begin{array}{l}\text { [76] quando as restrições quanto } \\
\text { ao uso do mercúrio, }\end{array}$ & [77] por causa da sua toxicidade, \\
\hline $\begin{array}{l}\text { [78] fizeram com que deixassem } \\
\text { de ser produzidos na Europa. }\end{array}$ & [79] Apesar disso, a invenção de Torricelli, \\
\hline $\begin{array}{l}\text { [80] nascida da vontade de ques- } \\
\text { tionar dogmas há muito tempo } \\
\text { aceitos }\end{array}$ & [81] sobre o vácuo e o peso do ar, é um exemplo notável \\
\hline $\begin{array}{l}\text { [82] de como pensar fora da caixa } \\
\text { - ou do tubo - }\end{array}$ & [83] pode ter um grande impacto. \\
\hline
\end{tabular}

Já os Grupos A e C retiraram esses comentários. Substituíram-nos por referências a características da ciência ilustradas pelos episódios históricos em questão. O Grupo A lembrou que o barômetro foi desenvolvido "com base na construção das ideias de vácuo e pressão do ar" (legenda 75). O grupo lembrou o caráter coletivo e provisório da ciência [81-82]. O Grupo C finalizou sua proposta para a animação registrando o prosseguimento da controvérsia envolvendo a pressão atmosférica e o horror ao vazio. Em trecho previamente citado, registram-se as lentas rupturas: "Isso mostra o quanto é trabalhoso mudar uma forte teoria vigente. [legendas 80-82]".

O Grupo D tentou, com alguma dificuldade na redação, retratar que os experimentos podem estar sujeitos a interpretações diversas, de modo que a argumentação com base em evidências empíricas (como o experimento de Torricelli) é passível de questionamento [legendas 79-83]. Ao contrário do tom apologético a Torricelli na animação original, o grupo optou por uma redação que relativiza o impacto de sua contribuição na época.

As propostas de roteiro elaboradas pelos grupos foram inseridas como legenda na animação "The History of the Barometer" e compartilhadas em apresentação da animação na aula final da disciplina de HFC. O resultado áudio-visual foi bastante positivo. Todas as propostas, em suas diferentes nuances, trouxeram avanços perceptíveis de qualidade se comparadas à animação original. Importante destacar, ainda, que as alterações nas legendas não se mostraram fora de sincronismo face aos quadros gráficos. Pelo contrário, um ajuste bastante razoável entre narração e informação visual pôde ser notado.

\section{Considerações finais}

À luz da fundamentação teórica decorrente da etapa formativa realizada na interven- 
ção didática, os licenciandos realizaram uma análise crítica bastante contundente da animação digital "The History of the Barometer". Perceberam diversos problemas no objeto virtual de aprendizagem: traços de historiografia Whig, Pedigree, anacronismos, visões de ciência simplistas, erros históricos e inadequações do ponto de vista gráfico. A percepção de tais problemas, aliada ao caráter fortemente atrativo da animação digital, motivou-os a buscarem alternativas que permitissem lidar com tais problemas por meio da edição do roteiro da animação original. Dessa forma, segundo os licenciandos, seria autorizada e possivelmente muito proveitosa a utilização da animação digital no contexto educacional.

A atividade de reelaboração de legendas para quadros gráficos já existentes oportunizou circunstância nas quais os grupos passaram das críticas bem fundamentadas à árdua tarefa de trabalhar em etapa de transposição didática da HFC, valendo-se de elementos valorados por eles próprios. Os relatos das dificuldades apresentados pelos quatro grupos revelam a percepção da complexidade da tarefa enfrentada por autores e equipe técnica que se propõem à elaboração de materiais didáticos para a introdução de conteúdos histórico-filosóficos, especialmente em animações de curta duração.

Por outro lado, o desempenho dos licenciandos demonstra que, ainda que com limitações, essa tarefa é possível se realizada de modo cuidadoso e lúcido, apoiada em conhecimento sobre o conteúdo histórico a ser tratado e fundamentação epistemológica adequada. Ao fazê-los também "autores" da animação, aspectos organizacionais e habilidades relacionadas a clareza, fluência e concisão na apresentação das ideias puderam ser trabalhadas. As propostas apresentadas pelos quatro grupos foram distintas entre si. Refletem as escolhas e a criatividade de cada grupo. Ainda assim, todas elas, sob o ponto de vista dos parâmetros estabelecidos no desafio à turma, são superiores à animação digital original.

Considerando não meramente os resultados das legendas, mas, sobretudo, os processos desenvolvidos durante a intervenção, têm-se aspectos positivos no sentido de que as atividades desenvolvidas se mostraram como espaço de reflexão crítica dos futuros docentes sobre o objeto virtual de aprendizagem com conteúdo histórico.

\section{Referências bibliográficas}

ALLCHIN, D. Scientific myth-conceptions. Science \& Education, Dordrecht, n. 87, v. 3, p. 329-351, 2003.

BALDINATO, J. O.; PORTO, P. A. Variações da História da Ciência no Ensino de Ciências. In: Encontro Nacional de Pesquisa em Educação em Ciências, VI, 2008, Belo Horizonte. Atas... Belo Horizonte: ABRAPEC, 2008.

BATISTA, G. L. F., DRUMMOND, J. M. H. F.; FREITAS, D. B. Fontes primárias no ensino de física: considerações e exemplos de propostas. Caderno Brasileiro de Ensino de Física, Florianópolis, v. 32, n. 3, p. 663-702, dez. 2015. 
BOAS, A. V.; SILVA, M. R.; PASSOS, M. M.; ARRUDA, S. M. História da Ciência e Natureza da Ciência: Debates e Consensos. Caderno Brasileiro de Ensino de Física, Florianópolis, v. 30, n. 2, p. 287-322, ago. 2013.

BOSS, S. L. B. Tradução comentada de artigos de Stephen Gray (1666-1736) e reprodução de experimentos históricos com materiais acessíveis - subsídios para o ensino de eletricidade. 2011. 350 f. Tese (Doutorado em Educação para a Ciência) - Faculdade de Ciências, UNESP, Bauru.

BRASIL. Orientações Educacionais Complementares aos Parâmetros Curriculares Nacionais para o Ensino Médio. Ciências da natureza, Matemática e suas tecnologias. Ministério da Educação/Secretaria da Educação Média e Tecnológica, Brasília. 2002.

CARVALHO, A. M. P.; GIL-PÉREZ, D. Formação de professores de ciências: tendências e inovações. São Paulo: Cortez, 1998.

COSTA, M. Uma abordagem histórico-didática com auxílio de multimídias para o ensino de partículas elementares no ensino médio. 2015. Dissertação (Mestrado em Ensino de Ciências e Educação Matemática) - Programa de Pós-Graduação em Ensino de Ciências e Educação Matemática, UEL, Londrina.

DRUMMOND, J. M. HIDALGO F. et al. Narrativas históricas: gravidade, sistemas de mundo e natureza da ciência. Caderno Brasileiro de Ensino de Física, Florianópolis, v. 32, p. 99-141, 2015.

DUARTE, M. C. A história da ciência na prática de professores portugueses: implicações para a formação de professores de ciências. Ciência \& Educação, Bauru, v. 10, n. 3, p. 317331, 2004.

FERREIRA, A. M. P; FERREIRA, M. E. M. P. A história da ciência na formação de professores. História da Ciência e Ensino: Construindo Interfaces. São Paulo, v. 2, p. 1-13, 2010.

FONSECA, D. S. et al. Pressão atmosférica e natureza da ciência: uma sequência didática englobando fontes primárias. Caderno Brasileiro de Ensino de Física, Florianópolis, v. 34, n. 1, p. 64-108, maio 2017.

FORATO, T. C. M.; PIETROCOLA, M.; MARTINS, R. A. Enfrentando obstáculos na transposição didática da história da ciência para a sala de aula. Pp. 123-154. In: PEDUZZI, L. O. Q.; MARTINS, A. F. P., FERREIRA, J. M. H. (org.). Temas de história e filosofia da ciência no ensino. Natal: EDUFRN, 2012.

FORATO, T. C. M.; PIETROCOLA, M.; MARTINS, R. A. Historiografia e natureza da ciência na sala de aula. Caderno Brasileiro de Ensino de Física, Florianópolis, v. 28, p. 27-59, 2011. 
FORATO, T. C. M. A natureza da ciência como saber escolar: um estudo de caso a partir da história da luz. 2009. 442 f. Tese (Doutorado em Educação) - Faculdade de Educação, USP, São Paulo.

GEWAndsznAJDer, F. Projeto Teláris - Ciências - $6^{0}$ Ano. 2. ed. São Paulo: Ática, 2015.

GIL PÉREZ, D. et al. Para uma imagem não deformada do trabalho científico. Ciência \& Educação, Bauru, v. 7, n. 2, p. 125-153, 2001.

GOULART, S. M. História da ciência: elo da dimensão transdisciplinar no processo de formação de professores de ciências. In: LIBÂNEO, J. C.; SANTOS, A. (orgs.). Educação na era do conhecimento em rede e transdisciplinaridade. Campinas: Alínea, 2005.

GRANT, E. Much ado about nothing: theories of space and vacuum from the Middle Ages to the Scientific Revolution. Cambridge: Cambridge University Press, 1981.

HENRIQUE, A. B.; COLOMBO JÚNIOR, P. D. Big Bang Brasil: uma peça teatral com abordagem histórico-filosófica para o ensino de cosmologia. In: SIMPÓSIO NACIONAL DE EDUCAÇÃO EM ASTRONOMIA, 1, 2011, Rio de Janeiro. Atas...

HIDALGO, J. M.; ALVES, J. M.; SOUZA, F. A.; QUEIROZ, D. M. Queiroz “A história da ciência (distorcida ou ausente) em livros didáticos: o conteúdo sobre o 'experimento de Torricelli' como estudo de caso". Alexandria: Revista de Educação em Ciência e Tecnologia, Florianópolis, v. 11, n. 1, p. 101-124, 2018.

MAGIE, W. F. A source book in Physics. Cambridge, MA: Harvard University Press, 1969.

MARTINS, A. F. P. História e filosofia da ciência no ensino: Há muitas pedras nesse caminho. Caderno Brasileiro de Ensino de Física, Florianópolis, v. 24, n. 1, p. 112-131, abr. 2007.

MARTINS, R. A. Introdução: a História da Ciência e seus usos na Educação. In: SILVA, C.

C. Estudos de história e filosofia das ciências: subsídios para aplicação no ensino. São Paulo: Livraria da Física, 2006.

MARTINS, R. A. O vácuo e a pressão atmosférica, da antiguidade a Pascal. Cadernos de História e Filosofia da Ciência, Campinas, v. 1, n. 3, p. 9-48, 1989. (a)

MARTINS, R. A. Tratados Físicos de Blaise Pascal. Seleção e tradução. Cadernos de História e Filosofia da Ciência, Campinas, v. 1, n. 3, p. 49-167, 1989. (b)

MATTHEWS, M. R. História, Filosofia e ensino de ciências: a tendência atual de reaproximação. Caderno Catarinense de Ensino de Física, Florianópolis, v. 12, n. 3, p. 164-214, 1995. 
MEDEIROS, A.; MONTEIRO JUNIOR, F. N. Reconstrução de experimentos históricos como uma ferramenta heurística no ensino de Física. In: ENCONTRO NACIONAL DE PESQUISA EM EDUCAÇÃO EM CIÊNCIAS, III, 2001, Atibaia, SP. Atas...

MERCADO, L. P. Formação continuada de professores e novas tecnologias. Maceió: EDUFAL, p. 176, 1999.

NICÁCIO, J. D. S. Formação docente para a inserção da História e Filosofia da Ciência no ensino: textos histórico-pedagógicos em discussão. 2015. 239 f. Dissertação (Mestrado Profissional em Ensino de Ciências Naturais) - Centro de Ciências Exatas e da Terra, UFRN, Natal.

OLIVEIRA, R. A.; SILVA, A. P. B. A História da Ciência no Ensino: diferentes enfoques e suas implicações na compreensão da ciência. In: ENCONTRO NACIONAL DE PESQUISA EM EDUCAÇÃO EM CIÊNCIAS, VII, 2011, Campinas. Atas...

PEDUZZI, L. O. Q. Sobre a utilização didática da História da Ciência. In: PIETROCOLA, M. (org.) Ensino de Física: conteúdo, metodologia e epistemologia numa concepção integradora. Florianópolis: Ed. da UFSC, 2001.

PEDUZZI, L. O; MARTINS A. F., FERREIRA J. M. Temas de história e filosofia da ciência no ensino. Natal: EDUFRN, 2012.

PEDUZZI, L. O. Q.; TENFEN, D. N.; CORDEIRO, M. D. Aspectos da natureza da ciência em animações potencialmente significativas sobre a História da Física. Caderno Brasileiro de Ensino de Física, Florianópolis, p. 758-786, set. 2012.

PEREIRA, G. J. S. A. História e filosofia da ciência nos currículos das licenciaturas em Física e Química da UFRN. 235 f. 2009. Dissertação (Mestrado em Educação) - Centro de Educação, UFRN, Natal.

PEREIRA, G. J. S. A.; MARTINS, A. F. P. A inserção de disciplinas de conteúdo históricofilosófico no currículo dos cursos de licenciatura em Física e em Química da UFRN: uma análise comparativa. Caderno Brasileiro de Ensino de Física, Florianópolis, v. 28, p. 229$258,2011$.

RINALDI, E.; GUERRA, A. História da ciência e o uso da instrumentação: construção de um transmissor de voz como estratégia de ensino. Caderno Brasileiro de Ensino de Física, Florianópolis, v. 28, n. 3, p. 653-675, jan. 2011.

RODRIGUES, E. V.; ZIMMERMANN, E.; HARTMANN, Â. M. Lei da gravitação universal e os satélites: uma abordagem histórico-temática usando multimídia. Ciência \& Educação, Bauru, v. 18, n. 3, p. 503-525, 2012. 
SILVA, A. P. B.; GUERRA, A. História da Ciência e Ensino: Fontes Primárias e propostas para sala de aula. São Paulo: Editora Livraria da Física, 2015.

SILVA, C. C. (org.). Estudos de História e Filosofia das Ciências. São Paulo: Livraria da Física, 2006.

SOUZA, F. A. História da Física e Natureza da Ciência na formação docente. 2018. 293

f. Dissertação (Mestrado Profissional em Ensino de Ciências Naturais) - Centro de Ciências Exatas e da Terra, UFRN, Natal.

SOUZA, R. S.; SILVEIRA, A. F.; SILVA, A. P. B. Mídias digitais e abordagem histórica: seus usos no ensino de física. In: SILVEIRA, A. F. et al. (orgs.). Tecnologias e Educação. Campina Grande: EDUEPB, 2016. v. 2, p. 449-482.

TEIXEIRA, E. S.; GRECA, I. M.; FREIRE, O. The History and Philosophy of Science in Physics Teaching: A research synthesis of didactic interventions. Science \& Education, Dordrecht, v. 21, p. 771-796, 2009.

VANNUCCHI, A. I. História e Filosofia da Ciência: da Teoria para a Sala de Aula. 1997. Dissertação (Mestrado em Ensino de Física) - Ensino de Ciências (Física, Química e Biologia), USP, São Paulo.

VIDAL, P. H. O. A história da ciência nos livros didáticos de química do PNLEM 2007. 2009. 103f. Dissertação (Mestrado em Ensino de Ciências) - Programa Interunidades em Ensino de Ciências, USP, São Paulo.

VINHA, M. L. Criatividade em ação: roteiros de animações virtuais elaborados por alunos de ensino médio em física. 2007. 259 f. Tese (Doutorado em Educação) - Faculdade de Educação, USP, São Paulo.

\section{Apêndice 1}

Análise da Animação "The history of the barometer" - turma 2017.2 HFC licenciatura. [compilação das observações escritas realizadas pelos estudantes; procurou-se preservar a redação original]

Historiografia/ História Whig - Tende a separar os personagens em certos e errados. Afirma que "felizmente" descobriu-se que Aristóteles estava errado. O certo é sempre o ponto de vista do nosso tempo, do nosso contexto. O "horror ao vazio" é tratado como um dogma, mesmo nível do senso comum. Já a contestação que começa com Galileu é ciência. Salto de dois mil anos para "resolver" os questionamentos. 
Simplificação/ Não faz jus ao "horror ao vazio". Não explica as ideias de Aristóteles, não demonstra o que significavam. *Um estudante aponta que a simplificação pode ser por causa do tempo curto de duração da animação.

Anacronismo/Usa a expressão "pressão atmosférica" e o conceito tal como conhecemos hoje. Usa ideias posteriores para mostrar que Aristóteles estava errado. Os cientistas parecem saber as respostas previamente aos estudos. Fala em "peso" do ar, como se peso correspondesse à visão newtoniana, mas Newton nem havia nascido. O título da animação: a História do Barômetro; a descoberta do barômetro parece um resultado inevitável, que começa em caminho a partir do horror ao vazio e sua contestação. O caminho percorrido pelos cientistas parece ter como objetivo chegar ao produto atual, o barômetro.

História Pedigree/Personagens surgem como mentores de experimentos e ideias. Dispensa a ideia de processo. Torricelli é "o cara" por pensar fora do convencional. "Pensar fora da caixa, ou do tubo, pode ter um grande impacto", mostra Torricelli como um gênio, ressaltando individualismo.

Externalismo/ Necessidade presente em uma determinada época leva ao estudo de um caso - problema dos mineiros para bombear a água. Alguns estudantes consideram que o texto é internalista, apenas descrevendo o passo a passo de quem fez o que.

\section{Visões de Ciência}

Empirismo indutivismo/ O experimento é fator decisivo, crucial para comprovação. Personagens chegam a conclusões aparentemente óbvias por meio de experimentos. Torricelli viu que a coluna de mercúrio era equilibrada pela pressão do ar. O experimento da montanha coloca um ponto final na questão. Pela observação via-se claramente a presença do vazio, descobre-se o vácuo. (Berti e o "vácuo estável"). Relaciona o teste experimental com a prova, não considera que os experimentos foram profundamente discutidos.

Individualismo/ Apesar de em alguns momentos a atividade de um personagem coincidir com a de outro, as descobertas são apresentadas como individuais. Cada um fez algo e ninguém fez em conjunto. Somatório de contribuições de gênios. Não há diálogo entre os pensadores. O experimento do Puyde-Dôme é descrito como obra de Pascal, paternidade do experimento atribuído a um único indivíduo. A atuação de Périer (quem o fez a pedido de Pascal) e da equipe, que incluía pessoas influentes e padres não é citada. Descoberta atribuída a Torricelli. *Dois estudantes consideram que há cooperação, porque vários personagens são citados. Um estudante cita que aparentemente trabalham com cooperação, de forma linear, rumo ao produto final barômetro.

Linear e rupturas/ Apesar da apresentação de personagens discordando uns dos outros, a história se passa como se cada um desses personagens acrescentasse mais um tijolo do conhecimento atual. Sequência de personagens acrescentando conhecimentos indica linearidade.

Linearidade em toda a animação, descrição do passo a passo de quem fez o que. Um dos estudantes considera que não foi linear por trazer o horror ao vazio e a ruptura. 
Conteúdo histórico/Segundo os estudantes, alguns episódios não condizem com os registros históricos, há distorções rumo a um individualismo e inconsistência histórica. Exemplos: Discussão estagnada até Galileu. Nenhum questionamento ao "horror ao vazio" até o problema de elevação da água. Cita que a "ideia de existir vácuo não estava sendo bem aceita". Mais do que isso, historicamente o "horror ao vazio" era altamente aceito, inclusive na época de Pascal. Os conhecimentos atribuídos a Galileu não representam a ideia de que a coluna de mercúrio se comporta como uma corda; ele considerava a inadequação de um vazio extenso. Torricelli foi o primeiro a pensar na hipótese do peso do ar e discordava totalmente do horror ao vazio. No entanto, a hipótese já existia na época. E ele era cauteloso ao se referir ao horror ao vazio. Pascal subiu a montanha (e a subiu sozinho) para realizar o experimento com o mercúrio. (Périer e sua equipe excluída). Pascal subiu a montanha para comprovar a variação da pressão atmosférica (mas esse não era o objetivo de Pascal; considerava isso como ponto de partida e o experimento se inseria na controvérsia sobre o horror ao vazio). O vídeo não considera que os experimentos foram profundamente discutidos. O tubo utilizado por Berti parece ser de vidro (era de chumbo). Torricelli mediu a pressão atmosférica. Ele concluiu definitivamente que a pressão do ar era responsável pela sustentação da coluna de mercúrio (ele afirmou, mas tinha dificuldades e demonstrava hesitação; o experimento do Puy-de-Dôme, que é posterior, se insere na mesma linha de raciocínio de argumentar que a pressão do ar é responsável pela sustentação da coluna de mercúrio; o horror ao vazio era forte na época de Pascal). Torricelli não queria simplesmente mostrar a pressão atmosférica. Descrição inadequada do experimento de Berti. Diz que Berti fez um experimento "simples". No entanto, houve dificuldade, com a impossibilidade de visualização do conteúdo do tubo.

Berti não conseguiu um vazio estável. O sino utilizado no experimento tocou. Pascal não queria "cooperar" com Torricelli, inclusive não o cita em suas cartas. Fala sobre o "experimento ordinário do vácuo". Galileu, que morreu em 1642, parece questionar o experimento de Torricelli, realizado em 1644. Não cita que a ideia de substituir a água pelo mercúrio veio de Galileu.

\section{Apêndice 2}

\begin{abstract}
FIS0729 - História e Filosofia da Ciência

DESAFIO: Considerem os elementos identificados pela turma na análise da animação "A história do Barômetro" e as discussões em aula sobre transposição didática da HFC. Recriem, quadro a quadro, um roteiro o mais adequado possível para a animação. Cada grupo receberá uma síntese dos comentários da turma e a legenda da animação.

1 00:06,762 --> 00:00:11,233

É conhecida a afirmação de Aristóteles: "A Natureza tem horror ao vácuo",
\end{abstract}

Título: A História do Barômetro

2 00:11,233 --> 00:00:16,233

quando afirmou que não podia existir um verdadeiro vácuo, um espaço sem matéria, 3 00:16,233 --> 00:00:19,271 porque a matéria em volta imediatamente o preencheria.

4 00:19,438 --> 00:00:22,394

Felizmente, veio a saber-se que ele estava errado.

5 00:22,394 --> 00:00:25,318

$\mathrm{O}$ vácuo é um componente essen-

cial do barômetro,

6 00:25,318 --> 00:00:27,792

um instrumento para medir a pressão atmosférica.
7 00:27,792 --> 00:00:30,407

Como a pressão atmosférica está ligada à temperatura 8 00:30,407 --> 00:00:32,007 e depressa se transforma nela, 9 00:32,267 --> 00:00:36,183 pode contribuir para furacões, tornados e outros incidentes climáticos extremos.

10 00:36,183 --> 00:38,614

Um barômetro é um dos instrumentos mais essenciais 11 00:38,614 --> 00:42,040 para as previsões meteorológicas e para os cientistas.

12 00:42,040 --> 00:44,807

Como funciona o barômetro e como é que foi inventado? 
13 00:44,807 --> 00:46,723

Levou algum tempo.

14 00:46,723 --> 00:50,071

Porque a teoria de Aristóteles e de outros filósofos da Antiguidade,

15 00:50,071 --> 00:52,246

no que se referia à impossibilidade

do vácuo,

16 00:52,246 --> 00:55,246

parecia ser verdade na vida quotidiana,

17 00:55,246 --> 00:59,247

pouca gente pensou em pôr isso

em questão durante quase 2000

anos

18 00:59,256 --> 01:01,807

— até que a necessidade levantou

o problema.

19 01:01,807 --> 01:04,190

No início do século XVII, os mineiros italianos

20 01:04,190 -->:01:07,725

enfrentaram um problema grave

quando perceberam que as suas

bombas

21 01:07,725 --> 01:10,990

não conseguiam elevar a água a

mais do que a 10,3 metros de altu-

ra.

22 01:10,990 --> 01:15,015

Alguns cientistas, nessa época, incluindo um tal Galileu Galilei, 23:01:15,024 -->:01:17,260

propuseram que retirar o ar do tubo

24 01:17,476 --> 01:20,320

era o que fazia com que a água

substituísse o vazio.

25 01:20,320 --> 01:25,606

Mas essa força era limitada e só podia elevar 10,3 metros de água.

26 01:25,606 --> 01:28,523

Porém, a ideia de existir um vácuo 27 01:28,523 --> 01:30,728 ainda era considerada controversa. 28 01:30,728 --> 01:33,647

A polêmica sobre a teoria pouco ortodoxa de Galileu

29 01:33,647 --> 01:38,339

levou Gasparo Berti a fazer uma

experiência simples mas brilhante

30 01:38,339 --> 01:40,343

para demonstrar que era possível.

31 01:40,379 --> 01:42,627

Encheram um tubo comprido com água

32 01:42,627 --> 01:46,512 e colocaram-no numa bacia baixa com as duas extremidades mergulhadas.

33 01:46,512 --> 01:48,948

Depois abriram uma das extremidades do tubo

34 01:48,948 --> 01:51,429

e despejaram água para a bacia

3501:51,429 --> 01:56,096

até que o nível da água que se

manteve no tubo ficou a 10,3

metros,

36 01:56,096 --> 02:00,483

com um espaço no cimo, sem que tenha entrado nenhum ar no tubo. 37:02:00,483 -->02:04,817

Berti tinha conseguido criar diretamente um vácuo estável.

38 02:04,817 --> 02:08,738

Mas, apesar de ter sido demonstrada a possibilidade de um vácuo, 39 02:08,738 --> 02:11,577

nem todos ficaram satisfeitos com a ideia de Galileu

40 02:11,577 --> 02:14,604

de que esse vácuo estivesse exercendo alguma força misteriosa, 41 02:14,604 --> 02:17,243 embora finita, sobre a água. 42 02:17,243 --> 02:21,198 Evangelista Torricelli, pupilo e amigo de Galileu,

43 02:21,198 --> 02:23,876

decidiu olhar para o problema por um ângulo diferente.

44 02:23,876 --> 02:28,265

Em vez de se concentrar no espaço vazio no interior do tubo, interrogou-se:

45 02:28,265 --> 02:30,760

"Que outra coisa poderá estar influenciando a água?"

46 02:30,760 --> 02:34,519

Porque a única coisa em contato com a água era o ar em volta da bacia.

47 02:34,519 --> 02:38,392

Ele pensou que a pressão do ar era a única coisa que podia estar impedindo

48 02:38,392 --> 02:41,513

que o nível da água no tubo caísse ainda mais.

49 02:41,513 --> 02:45,551

Percebeu que a experiência não era somente uma forma de criar o vácuo,
50 02:45,551 --> 02:47,496 mas funcionava como um equilíbrio

51 02:47,504 --> 02:50,872

entre a pressão atmosférica sobre a água, no exterior do tubo,

52 02:50,872 --> 02:54,111

e a pressão da coluna de água dentro do tubo.

53 02:54,111 --> 02:58,809

O nível da água no tubo diminui até que as pressões estejam iguais, 54 02:58,809 --> 03:02,342

o que acontece quando a água está a 10,3 metros.

55 03:02,742 --> 03:04,813

Esta ideia não foi aceita facilmente,

56 03:04,813 --> 03:07,711

porque Galileu e outros tinham pensado

57 03:07,711 --> 03:12,355

que o ar atmosférico não tinha peso e não exercia pressão.

58 03:12,355 --> 03:14,898

Torricelli resolveu repetir a experiência de Berti

59 03:14,898 --> 03:17,117

com mercúrio em vez de água.

60 03:17,117 --> 03:20,393

Porque o mercúrio era mais denso, caía mais do que a água

61 03:20,393 --> 03:24,619

e a coluna de mercúrio elevava-se apenas a 76 centímetros de altura. 62 03:24,619 --> 03:28,836

Isto permitiu que Torricelli tornasse o instrumento mais compacto, 63 03:28,836 --> 03:33,320

Mas comprovou a sua ideia de que o peso era o fator decisivo.

64 03:33,320 --> 03:35,489

Numa variante da experiência usou dois tubos

65 03:35,489 --> 03:37,911

em que um deles tinha uma grande bolha no topo.

66 03:37,911 --> 03:40,480

Se a interpretação de Galileu estivesse correta,

67 03:40,480 --> 03:42,574

o vácuo maior, no segundo tubo, 68 03:42,574 --> 03:46,710

devia exercer maior sucção e elevar o mercúrio mais alto. 69 03:46,710 --> 03:49,106 
Mas o nível em ambos os tubos manteve-se o mesmo.70

03:49,106 --> 03:53,293

$\mathrm{O}$ apoio final para a teoria de Torricelli apareceu através de Blaise Pascal

71 03:53,293 --> 03:56,466 que levou um tubo de mercúrio para o alto de uma montanha 72 03:56,466 --> 03:58,603 e demonstrou que o nível de mercúrio descia

73 03:58,603 --> 04:02,031

quando a pressão atmosférica diminuía com a altitude.

\section{Legenda editada - Grupo A}

1 É conhecida a afirmação de Aristóteles: "A Natureza tem horror ao vácuo",

2 Quando afirmou que não podia existir um verdadeiro vácuo, um espaço sem matéria,

3 Porque a matéria em volta imediatamente o preencheria.

4 Mas esse era apenas um dos pensamentos da época.

5 Temos aqui um modelo ilustrativo de "barômetro".

6 Hoje é bastante aceito que o ar exerce pressão sobre os corpos,

7 Incluindo líquidos. Aceita-se que a pressão varia

8 de acordo com a altitude, como mostra a ilustração.

9 O barômetro que conhecemos tem diversas aplicações dependendo da necessidade humana.

10 Contudo, tal barômetro não surgiu de repente, assim como

11 a ideia de pressão atmosférica também não. Foram séculos de discussões.

12 Como funciona um barômetro e como foi desenvolvido?

13 Levou algum tempo.

14 Porque a teoria de Aristóteles e de outros filósofos da Antiguidade, 15 no que se referia à impossibilidade do vácuo,

16 Parecia ser aceita na vida quotidiana.

17 Muitos pensadores discutiram sobre isso em 2000 anos através de
74 04:02,389 --> 04:05,734

Os barômetros de mercúrio, baseados no modelo original de Torricelli,

75 04:05,734 --> 04:10,607

mantiveram-se uma das formas

habituais de medir a pressão atmosférica até 2007 ,

76 04:10,607 --> 04:12,862

quando as restrições quanto ao uso do mercúrio,

77 04:12,862 --> 04:14,237

por causa da sua toxicidade,

78 04:14,237 --> 04:16,953

fizeram com que deixassem de ser produzidos na Europa.

\section{Apêndice 3}

discussões filosóficas,

18 experimentos reais e imaginários.

19 No início do século XVII, os mineiros italianos

20 Enfrentaram um problema quando perceberam que as suas bombas

21 não conseguiam elevar a água a mais do que 9,4 toesas $(10,3$ metros) de altura.

22 Alguns pensadores, nessa época, incluindo um tal Galileu Galilei,

23 propuseram que retirar o ar do tubo.

24 era o que fazia com que a água substituísse o vazio.

25 Mas essa ação era limitada e só podia elevar 9,4 toesas de água.

26 Porém, a hipótese da existência de um vácuo

27 ainda era considerada controversa.

28 O Prof. Milton nos ajudará a compreender melhor a situação...

29 Imaginemos o seguinte experimento para essa ideia de vácuo da época:

30 Enche-se com água um tubo,

31 Mergulha-o pelas extremidades 32 numa bacia d'água baixa. O tubo era de chumbo devido a circunstâncias da época.33 Depois de abrir uma das extremidades

34 a água é despejada do tubo pra bacia.

35 A altura da água se mantém em
79 04:16,953 --> 04:19,157

Apesar disso, a invenção de Torricelli,

80 04:19,157 --> 04:22,434

nascida da vontade de questionar dogmas há muito tempo aceitos 81 04:22,434 --> 04:26,180 sobre o vácuo e o peso do ar, é um exemplo notável

82 04:26,180 --> 04:29,202

de como pensar fora da caixa ou do tubo -

83 04:29,202 --> 04:31,139

pode ter um grande impacto.

9,4 toesas, ou 10,3 metros atualmente,

36 com um espaço no cimo, sem que tenha entrado nenhum ar no tubo.

37 Teríamos, então, um vácuo estável agora? Que questão interessante!

38 Esse experimento é semelhante ao da época. Contudo, apenas isso 39 não foi suficiente para convencer todos os pensadores da época 40 de que ele existia e/ou exercia alguma ação, mesmo que finita,

41 sobre a água, como defendia Galileu e outros.

42 Com base em uma carta de Torricelli ao seu amigo Ricci observamos

43 aspectos de dúvidas sobre a ação do vácuo.

44 Investigações filosóficas e empiristas o levaram a questões como:

45 "Que outra coisa poderá estar influenciando a água?"

$46 \mathrm{E}$ através delas ele pensou que o ar poderia influenciar no experimento.

47 Sendo assim, o ar estaria realmente exercendo pressão sobre a água?

48 Ele percebeu que apenas isso poderia ser suficiente para explicar

49 o fenômeno. Todavia, nunca abandonou o pensamento que prevalecia. 
50 Tais questões o acompanham durante toda a carta.

51 A influência do ar é parecida com a pressão atmosférica atual.

$52 \mathrm{O}$ que ele pode ter pensado foi que

53 talvez o nível da água no tubo diminuísse até que as pressões (água-ar) fossem iguais,

54 mas não necessariamente 9,4 toesas (10,3 metros),

55 pois não havia realizado medições.

56 Alguns historiadores argumentam

57 que Gallileu sugeriu a Torricel-

li, através de uma conversa,

58 usar mercúrio ao invés de água e ele o fez.

59 A coluna de mercúrio era menor que a da água no tubo.

60 Isso tornou o experimento mais compacto e o equilíbrio permanecia.

61 Estima-se que a coluna estabilizou aproximadamente em $76 \mathrm{~cm}$ em medidas atuais,

62 auxiliando-o nos estudos e desenvolvimento de suas ideias, mesmo sem medições.

63 Assim, estimulando ainda mais um pensamento sobre algo além do vácuo no experimento.

64 Numa variante da experiência usou dois tubos

65 Em que um deles tinha um grande bulbo no topo.

66 Se a interpretação de Galileu

fosse coerente,

67 o vácuo maior, no segundo tubo,

68 deveria exercer maior sucção e elevar o mercúrio mais alto.

69 Mas o nível em ambos os tubos manteve-se o mesmo.

70 Vejamos o experimento do ponto de vista do Blaise Pascal, em que

71 Florin Périer, seu cunhado, juntamente com 4 testemunhas subiram

72 o monte Puy-de-Dôme com alguns experimentos semelhantes 73 deixando um em sua casa. À medida que subiam
74 perceberam que a coluna de mercúrio variava com a altura, como o barômetro.75 O instrumento barômetro foi desenvolvido posteriormente, com base na construção das ideias de vácuo e pressão do ar.

76 Lembram do mercúrio utilizado anteriormente?

77 Por causa da sua toxidade, 78 deixou de ser utilizado, pelos seus efeitos nocivos à saúde.

79 Então, pessoal, gostaram da história?

80 Espero que sim! Podemos perceber alguns aspectos da Natureza da Ciência.

81 Ela não nasce do dia para a noite, é um processo de construção,

82 em que há contribuições diversas e muitas discussões,

83 chegando em alguma ideia aceita temporariamente.

\section{Legenda editada - Grupo B}

1 É conhecida a afirmação de Aristóteles: "A Natureza tem horror ao vácuo",

2 quando afirmou que não podia existir um verdadeiro vácuo, um espaço sem matéria,

3 porque a matéria em volta imediatamente o preencheria.

4 Mas atualmente, acreditamos que as coisas não são bem assim.

$5 \mathrm{O}$ vácuo é um componente essencial do barômetro,

6 um instrumento para medir a pressão atmosférica.

7 Como a pressão atmosférica está

ligada à temperatura

8 ao estudar sua variação,

9 podemos entender melhor furacões, tornados e outros incidentes climáticos extremos.

10 Um barômetro é um dos instrumentos mais essenciais

11 para as previsões meteorológicas e para os cientistas.

12 Como funciona o barômetro e como é que foi inventado?

$13 \mathrm{Bem}$, levou algum tempo.

14 A teoria de Aristóteles e de outros filósofos da Antiguidade, quotidiana,
15 no que se referia à impossibilidade do vácuo,

16 parecia ser verdade na vida 18 até que a necessidade levantou o problema.

19 No início do século XVII, alguns mineiros

20 enfrentaram um problema grave quando perceberam que as suas bombas

21 não conseguiam elevar a água a mais do que a 10,3 metros de altura.

22 Alguns estudiosos, nessa época, incluindo um tal Galileu Galilei,

23 propuseram que retirar o ar do tubo

24 era o que fazia com que a água substituísse o vazio.

25 Mas essa força era limitada e só podia elevar 10,3 metros de água

26 Porém, a ideia de existir um vácuo

27 ainda era considerada controversa.

28 A polêmica sobre a teoria pouco ortodoxa de Galileu

29 levou Gasparo Berti a fazer uma experiência interessante e brilhante

30 para verificar se era possível.

31 Encheram um longo tubo de chumbo com água

32 e colocaram-no numa bacia baixa com as extremidades fechadas.

33 Depois abriram uma da extremidades do tubo

34 e perceberam água fluir para a bacia

35 até que o nível da água que se manteve no tubo ficou a 10,3 metros,

36 deveria então haver um espaço no cimo, mesmo sem ter entrado nenhum ar no tubo.

37 Berti tinha conseguido criar provavelmente um vácuo na parte superior do tubo.

38 Entretanto, não era possível enxergar a altura da água e o vácuo,

39 e nem todos ficaram satisfeitos com a ideia de Galileu 
40 de que esse vácuo estivesse exercendo alguma força misteriosa,

41 embora finita, sobre a água.

42 Evangelista Torricelli, pupilo e amigo de Galileu,

43 decidiu olhar para o problema por um ângulo diferente.

44 Apesar de se preocupar com o espaço vazio no interior do tubo, interrogou-se:

45 "Que outra coisa poderá estar a influenciar a água?"

46 Porque a única coisa em contacto com a água era o ar em volta da bacia.

47 Ele pensou que o peso do ar sobre a superfície do líquido

48 podia estar a impedir que o nível da água no tubo caísse ainda mais.

49 Percebeu que a experiência não era somente uma forma de estudar o vácuo,

50 mas também de estudar o equilíbrio

51 entre o peso do ar sobre a água, no exterior do tubo,

52 e o peso da coluna de água dentro do tubo.

53 O nível da água no tubo deve diminuir até que os pesos estejam iguais,

54 o que acontece quando a água está a 10,3 metros.

55 Esta ideia não foi aceita facilmente,

56 porque outros estudiosos pensavam

57 que o ar atmosférico não tinha peso e não exercia pressão.

58 Torricelli resolveu repetir a experiência de Berti

59 com mercúrio em vez de água.

60 Pois o mercúrio, sendo mais denso, deveria cair mais do que a água

61 e viu que a coluna de mercúrio se mantinha apenas a 76 centímetros de altura.

62 Isto permitiu que Torricelli tornasse o instrumento mais compacto

63 e reforçou a sua ideia de que o peso era o fator influente.

64 Numa variante da experiência usou dois tubos
65 em que um deles tinha uma grande bolha no topo.

$66 \mathrm{Se}$ o horror ao vazio estivesse

correto,

67 o vácuo maior, no segundo tubo,

68 devia exercer maior sucção e elevar o mercúrio mais alto. Mas o nível em ambos os tubos mantevese o mesmo.

70 A partir do experimento de Torricelli, Blaise Pascal dedicouse a algumas ideias

71 que seria levar um tubo de mercúrio para o alto de uma montanha

72 e verificar o quanto o nível de mercúrio descia

73 relacionando isto à pressão atmosférica que em teoria diminuiria com a altitude.

74 Os barômetros de mercúrio, baseados no experimento feito por Torricelli,

75 mantiveram-se uma das formas habituais de medir a pressão atmosférica até 2007 ,

76 quando as restrições quanto ao uso do mercúrio,

77 por causa da sua toxicidade,

78 fizeram com que deixassem de ser produzidos na Europa.

79 Deste modo, as discussões sobre o vazio

80 nascidas da necessidade de questionar dogmas e resolver problemas

81 surgidos ao longo da história é um exemplo notável

82 de como pensar fora da caixa - ou do tubo -

83 pode ter um grande impacto.

\section{Legenda editada - Grupo C}

1 É conhecida a afirmação de Aristóteles: "A Natureza tem horror ao vácuo"

2 quando afirmou que não poderia existir um verdadeiro vácuo, um espaço sem matéria,

3 porque a matéria em volta imediatamente o preencheria.

4 Futuramente, veio a saber que foi contestado.

5 Outros afirmaram que podia existir, mas com muita dificuldade.
6 Depois de muita discussão, cientistas diziam que o ar tinha peso e exercia pressão,

7 mas a explicação para a sustentação do líquido não era unânime,

8 já que o horror ao vazio poderia talvez variar com a altura.

9 Hoje, nós temos explicações totalmente diferentes.

$10 \mathrm{E}$ graças a diversos debates históricos, conseguimos instrumentos de medida

11 daquilo que chamamos hoje de

"Pressão atmosférica".

12 Mas como se deu o processo de construção desse conceito atual?

13 Não foi nada simples.

14 Aristóteles dizia "Os movimentos podem ser explicados sem a existência do vazio!"

15 "Se uma flecha se move para frente, o ar na frente dela..."

16 "...é direcionado para trás, impulsionando-a para frente."

17 E muitos concordavam plenamente.

18 Tal explicação perdurou muito tempo.

19 No início do século XVII, os mineiros italianos

20 enfrentaram um problema grave, quando perceberam que as suas bombas

21 não conseguiam elevar a água a mais do que 10,3 metros de altura. 22 Alguns cientistas, nessa época, incluindo Galileu Galilei,

23 propuseram que retirar o ar do tubo

24 fazia a água se "esticar" para ocupar o espaço vazio.

25 Mas esse "esticamento" era limitado e só podia elevar 10,3 metros de água.

26 Porém, a ideia de existir um vazio

27 ainda era controversa.

28 A polêmica sobre a teoria pouco ortodoxa de Galileu

29 levou Gasparo Berti a fazer uma experiência para investigar 30 mais sobre o possível espaço vazio.

31 Encheram com água um enorme tubo de cobre,

32 com um sino dentro, no topo, e colocaram num tonel com água. 
33 Depois, abriram uma das extremidades do tubo

34 e despejaram água para o tonel, 35 até que o nível da água se manteve no tubo, estável,

36 com um espaço no cimo, sem que tenha entrado nenhum ar no tubo.

37 Eles tocaram o sino do topo e não o ouviram.

38 Isso indicava que o espaço ali estava mesmo vazio.

39 Alguns cientistas não ficaram satisfeitos com a ideia.

40 Outros acreditavam que o vazio existia, e exerceria ainda

41 uma força finita sobre a água.

42 Evangelista Torricelli, aluno de Galileu,

43 decidiu investigar mais o experimento proposto por Berti.

44 Se concentrou na parte de cima do tubo, mas também interrogouse:

45 "O que mais poderia sustentar a água?"

46 "O que mais?"

47 Torricelli considerou que o ar em volta do tonel poderia ser essa influência.

48 Mas ficou bastante confuso com as possibilidades, já que

49 o peso do ar não excluiria o horror ao vazio, amplamente aceito na época.

50 Torricelli não queria ser o "do contra". Ele considerou que poderia ser possível

51 haver um balanço entre a pressão do ar sobre a água, no exterior do tubo,

$52 \mathrm{e}$ as pressões ou forças internas dentro do tubo.

$53 \mathrm{O}$ nível da água diminuiria até chegar ao equilíbrio,

54 o que acontece quando a água está a 10,3 metros.

55 Torricelli lembrara um dia do falecido professor

56 que numa conversa teria sugerido a ele:

57 "Tente fazer o experimento com mercúrio, não com água!"

58 Torricelli seguiu a sugestão e o repetiu com mercúrio.

59 "Com o líquido mais pesado da natureza, posso construir..."
60 "... o experimento de Berti num tamanho menor!"

61 Ele observou a coluna de mercúrio elevar-se apenas a 76 centímetros de altura.

62 A grande vantagem desse experimento não era só o tamanho,

63 mas permitia ver dentro do tubo, o que não era possível com tubo metálico.

64 Tentando argumentar contra o horror ao vazio,

65 numa variante da experiência usou dois tubos

66 em que um deles tinha um grande bulbo no topo,

67 Se a razão da sustentação fosse interna,

68 no segundo tubo, o mercúrio deveria elevar-se mais, pois o vazio era maior.

69 Mas o nível de ambos os tubos se manteve o mesmo.

70 Em 1648, Florin Périer subiu o

Puy-de-Dôme, levando tubos com mercúrio.

$71 \mathrm{Fez}$ isso a pedido de um parente, para ver se o nível caía ao longo da subida,

72 já sabendo que a pressão do ar diminuía com a altitude.

$73 \mathrm{E}$ as expectativas do cunhado, Blaise Pascal, foram observadas.

74 Os barômetros atuais de mercúrio, baseados no modelo de Torricelli,

75 mantiveram-se uma das formas habituais de medir a pressão atmosférica até 2007 ,

76 quando as restrições quanto ao uso do mercúrio,

77 por causa de sua toxicidade,

78 fizeram com que deixassem de ser produzidos na Europa.

79 Apesar disso, mesmo com tantas observações

80 e argumentos que corroboraram com a teoria da "Pressão Atmosférica",

81 as investigações continuaram até que o horror ao vácuo foi perdendo seguidores.

82 Isso mostra o quanto é trabalhoso

83 mudar uma forte teoria vigente.

\section{Legenda editada - Grupo D}

1 É notório o argumento de Aristóteles: "a natureza tem horror ao vazio",

2 Quando afirmou que não podia existir um verdadeiro vácuo, um espaço sem matéria,

3 Porque a matéria em volta imediatamente o preencheria

4 Ideia essa que permaneceu ecoando por quase dois milênios

5 o vácuo é um conceito essencial para se entender a pressão atmosférica

6 Que possui grande importância na sociedade.

7 Como a pressão atmosférica está ligada a temperatura

8 e depressa se transforma nela

9 pode contribuir para furacões, tornados e outros incidentes climáticos extremos

$10 \mathrm{O}$ que a torna essencial

11 para previsões meteorológicas e para os cientistas

12 e como os estudos sobre o vazio se desenvolveram?

13 Levou algum tempo

14 Porque a teoria de Aristóteles e de outros filósofos da Antiguidade,

15 no que se referia a impossibilidade do vácuo,

16 era amplamente aceita,

17 e foi pouco questionada por muito tempo

18 até que a necessidade levantou o problema.

19 No início do século XVII, os mineiros italianos

20 enfrentaram um problema grave quando perceberam que as suas bombas

21 não conseguiam elevar a água a mais do que 10,3 metros de altura. 22 Alguns cientistas, nessa época, incluindo Galileu Galilei

23 propuseram que retirar o ar do tubo

24 era o que fazia com que a água substituísse o vazio

25 mas essa força era limitada e só podia elevar 10,3 metros de água.

26. Porém, a ideia de existir um vácuo

27 ainda era considerada controversa. 
28 Havia polêmica sobre a existência e força do vácuo.

29 A polêmica levou Gasparo

Berti e seus colaboradores

30 demonstrar que era possível.

31 Encheram um tubo de chumbo comprido com água

32 e colocaram-no numa bacia baixa com as duas extremidades mergulhadas.

33 Depois abriram uma das extremidades do tubo

34 e despejaram água para a bacia

35 até que o nível da água que se manteve no tubo ficou a 10,3 metros

36 com um espaço no cimo, sem que tenha entrado nenhum ar no tubo.

37 Assim se deu o experimento do "vazio estável".

38 Mas, apesar de ter sido demonstrada a possibilidade de um vácuo, 39 nem todos ficaram satisfeitos com a outra ideia

40 de que o vácuo estivesse exercendo alguma força misteriosa,

41 embora finita, sobre a água.

42 Evangelista Torricelli, aluno e amigo de Galileu

43 decidiu olhar para o problema pela visão de Isaac Beeckman

44 que fez uma comparação. Assim como a água pressionava tudo imerso nela, ele fez ...

45 o ar deveria comportar-se assim também

46 porque a única coisa em contato com a água era o ar em volta da bacia.

47 Concluiu então que a pressão do ar era a única coisa que podia estar impedindo
48 que o nível da água no tubo caísse ainda mais.

49 Percebeu que o experimento não era somente uma forma de demonstrar um vácuo estável,

50 mas funcionava como um equilíbrio

51 entre a pressão atmosférica sobre a água, no exterior do tubo,

52 e a pressão da coluna de água dentro do tubo.

53 O nível da água no tubo diminui até que as pressões estejam iguais

54 o que acontece quando a água está a 10,3 metros.

55 Esta ideia não foi aceita facilmente

56 porque muitos tinham pensado

57 que o ar atmosférico não exercia pressão.

58 Galileu deu a ideia a Torricelli para ele repetir o experimento de Berti

59 com mercúrio em vez de água,

60 porque o mercúrio era mais denso, caía mais do que a água 61 e a coluna de mercúrio elevava-se apenas a 76 centímetros. 62 Isto permitiu fazer um experimento compacto e usando vidro.

63 Mas evidenciou a sua ideia de que a pressão do era o fator decisivo

64 numa variante de experiência.

Usou dois tubos

65 em que um deles tinha uma grande bolha no topo.

66 Se o vazio exercesse uma força, ele argumentou,

67 o vácuo maior, no segundo tubo
68 deverá exercer uma força maior, elevando mais o mercúrio.

69 Mas o nível de ambos manteve-se o mesmo.

70 O apoio para a teoria de Torricelli apareceu através de Blaise Pascal.

71 Que inspirado por Descartes pediu para que seu cunhado Périer,

72 junto a uma comitiva, subisse uma montanha realizando o experimento em diferentes altitudes.

73 Para mostrar que o nível de mercúrio variava de acordo com a altitude.

79 O experimento de Torricelli, 74 Após tudo isso a ideia de pressão atmosférica não conseguiu tantos adeptos

75 e só veio ser aceita futuramente, de forma natural e gradativa

76 e a ideia do "horror ao vazio" sem ter a necessidade de ser refutada.

77 Os argumentos empíricos não sustentavam apenas as ideias de Torricelli,

78 mas também a argumentação oposta, que continuou forte. 80 nascido de uma vontade de evidenciar empiricamente suas ideias

81 sobre o vazio e a pressão do ar, é um exemplo notável

82 de que argumentar usando experimentos que tenham dupla interpretação

83 talvez não seja a melhor forma de argumentar. 